OPEN ACCESS

Edited by:

Oleg Palygin,

Medical College of Wisconsin,

United States

Reviewed by:

Tengis Pavlov,

Henry Ford Health System,

United States

Matthew Aaron Sparks,

Duke University, United States

Blythe D. Shepard,

Georgetown University Medical

Center, United States

*Correspondence:

Kate M. Denton

Kate.Denton@monash.edu

Specialty section:

This article was submitted to

Renal and Epithelial Physiology,

a section of the journal

Frontiers in Physiology

Received: 29 April 2020

Accepted: 03 June 2020

Published: 26 June 2020

Citation:

McArdle Z, Schreuder MF, Moritz KM, Denton KM and Singh RR (2020) Physiology

and Pathophysiology of Compensatory Adaptations of a

Solitary Functioning Kidney.

Front. Physiol. 11:725.

doi: 10.3389/fphys.2020.00725

\section{Physiology and Pathophysiology of Compensatory Adaptations of a Solitary Functioning Kidney}

\author{
Zoe McArdle ${ }^{1}$, Michiel F. Schreuder ${ }^{2}$, Karen M. Moritz ${ }^{3}$, Kate M. Denton ${ }^{1 *}$ and \\ Reetu R. Singh ${ }^{1}$ \\ ${ }^{1}$ Cardiovascular Program, Monash Biomedicine Discovery Institute and Department of Physiology, Monash University, \\ Melbourne, VIC, Australia, ${ }^{2}$ Department of Pediatric Nephrology, Amalia Children's Hospital, Radboud University Medical \\ Center, Nijmegen, Netherlands, ${ }^{3}$ Child Health Research Centre and School of Biomedical Sciences, University \\ of Queensland, Brisbane, QLD, Australia
}

Children born with a solitary functioning kidney (SFK) have an increased risk of hypertension and kidney disease from early in adulthood. In response to a reduction in kidney mass, the remaining kidney undergoes compensatory kidney growth. This is associated with both an increase in size of the kidney tubules and the glomeruli and an increase in single nephron glomerular filtration rate (SNGFR). The compensatory hypertrophy and increase in filtration at the level of the individual nephron results in normalization of total glomerular filtration rate (GFR). However, over time these same compensatory mechanisms may contribute to kidney injury and hypertension. Indeed, approximately 50\% of children born with a SFK develop hypertension by the age of 18 and $20-40 \%$ require dialysis by the age of 30 . The mechanisms that result in kidney injury are only partly understood, and early biomarkers that distinguish those at an elevated risk of kidney injury are needed. This review will outline the compensatory adaptations to a SFK, and outline how these adaptations may contribute to kidney injury and hypertension later in life. These will be based largely on the mechanisms we have identified from our studies in an ovine model of SFK, that implicate the renal nitric oxide system, the renin angiotensin system and the renal nerves to kidney disease and hypertension associated with SFK. This discussion will also evaluate current, and speculate on next generation, prognostic factors that may predict those children at a higher risk of future kidney disease and hypertension.

Keywords: solitary functioning kidney, compensatory hypertrophy, glomerular hyperfiltration, renal sympathetic nerves, renin angiotensin system, nitric oxide

\section{INTRODUCTION}

Congenital anomalies of the kidney and urinary tract (CAKUT) represent the primary cause of chronic kidney disease (CKD) in the pediatric population, accounting for approximately $50 \%$ of cases (Becherucci et al., 2016). A solitary functioning kidney (SFK) is a common abnormality in the spectrum of CAKUT and is characterized by a reduction in kidney mass and nephron number. For children born with a SFK, or who undergo unilateral nephrectomy early in life, the risk of hypertension, kidney injury and CKD is increased from early in life. As such, approximately $50 \%$ of children born with a SFK develop hypertension as early as the age of 18 years and $20-40 \%$ require dialysis by the age of 30 years (Sanna-Cherchi et al., 2009; Westland et al., 2013a). In contrast, in long-term studies it has been demonstrated that kidney function is well preserved 
following donation of a kidney in adulthood (Kasiske et al., 1995; Fehrman-Ekholm et al., 2001; Ibrahim et al., 2009). However, recent studies have reported that kidney donation can result in a small increase in the risk of kidney failure compared with healthy non-donors (Muzaale et al., 2014). Additionally, an increase in risk of kidney disease after donation is also observed in kidneys donors with pre-existing conditions such as obesity (Niemi and Mandelbrot, 2014). The mechanisms that underlie the differences in prognosis for loss of a kidney early in life compared with adulthood are not well understood but may be associated with differences in compensatory adaptations to loss of kidney mass. Following a reduction in kidney mass, the remaining kidney undergoes adaptive compensatory hypertrophy, of both the tubules and the glomeruli, and compensatory glomerular hyperfiltration to maintain kidney function. However, the mechanisms that facilitate these compensatory adaptations following a reduction in kidney mass may in the long-term contribute to the onset of hypertension and kidney injury. Although common prognostic indicators of kidney injury [hypertension, proteinuria, estimated GFR $(e G F R)<60 \mathrm{ml} / \mathrm{min} / 1.73 \mathrm{~m}^{2}$ ] have been observed in children born with an SFK from as early as 10 years of age, early markers at time of diagnosis of SFK, that distinguish those at an elevated risk of kidney injury are needed (Schreuder et al., 2008; Westland et al., 2011, 2013a).

\section{PREVALENCE OF A SFK}

Unilateral renal agenesis (URA) and multicystic dysplastic kidney (MCDK) are the two main abnormalities in the spectrum of CAKUT that result in a SFK (Schreuder et al., 2009; Westland et al., 2013b). There is a higher incidence of CAKUT in males compared with females (Kummer et al., 2012; Tain et al., 2016; Li et al., 2019). In a Taiwanese study, males had a 1.83 greater risk of CAKUT compared with females (Tain et al., 2016). Additionally, males with CAKUT advance to renal replacement therapy earlier than their female counterparts (Wuhl et al., 2013). URA is estimated to occur in 1 in $\sim 2000$ births (Westland et al., 2013b). MCDK is a severe form of renal dysplasia that can result in a non-functioning kidney and has an estimated incidence of 1 in $\sim 4300$ births (Schreuder et al., 2009). Both URA and MCDK are conditions of SFK that are congenital in origin. However, a SFK can also be acquired early in life following unilateral nephrectomy, which can be due to oncological (e.g., Wilm's tumor) or non-oncological causes (e.g., CAKUT such as pelviureteric junction obstruction, posterior urethral valves or vesicoureteral reflux) (Westland et al., 2013a; MavinkurveGroothuis et al., 2016).

\section{CLINICAL OUTCOMES}

The clinical outcomes of children with a congenital SFK or early-acquired SFK remain contentious. Data on the long-term cardiovascular and renal consequences of a congenital SFK are limited (summarized in Table 1) (Argueso et al., 1992;
Sanna-Cherchi et al., 2009; Wang et al., 2010; Xu et al., 2019). In a longitudinal study it was observed that of 71 patients with a congenital SFK $\sim 20-40 \%$ had begun dialysis by the age of 30 years (Sanna-Cherchi et al., 2009). In a Chinese study of 48 adults with a congenital SFK, 38.5\% had reduced GFR ( $<60 \mathrm{ml} / \mathrm{min} / 1.73 \mathrm{~m}^{2}$ ), 35.4\% had proteinuria and two individuals had begun dialysis by a mean age of $\sim 37$ years (Wang et al., 2010). Similarly, Xu et al. (2019) found that of 118 patients with URA, $43 \%$ had proteinuria and $25 \%$ had a reduced GFR $\left(<60 \mathrm{ml} / \mathrm{min} / 1.73 \mathrm{~m}^{2}\right)$ at a median age of 32 years. These studies indicate that there is a progressive loss of kidney function in individuals with a congenital SFK throughout adulthood, and in some individuals results in progression to kidney failure by 30-40 years of age.

The Kidney of MONofunctional Origin (KIMONO) longitudinal study is currently the largest cohort, with over 400 children with both congenital and early-acquired SFK, based in The Netherlands (Schreuder et al., 2008; Westland et al., 2011, 2013a). It was designed to study the prognosis of a SFK of different origins in childhood (Schreuder et al., 2008; Westland et al., 2011, 2013a). The KIMONO cohort comprised of patients with a 'primary' SFK of congenital origin, including both URA and MCDK, and a 'secondary' SFK of early-acquired origin following unilateral nephrectomy due to obstructive or reflux nephropathy (Westland et al., 2011, 2013a). These groups were further subdivided into those with and without ipsilateral CAKUT (in the remnant kidney) (Westland et al., 2011, 2013a). In this study kidney injury was defined as hypertension, proteinuria, reduced eGFR and/or the use of kidney protective medication [e.g., Angiotensin converting enzyme inhibitor (ACEi) or Angiotensin II receptor blockers (ARB)] and kidney length was measured by ultrasound (Westland et al., 2011, 2013a). The KIMONO study showed that approximately one in three children with a SFK had signs of kidney injury at a mean age of 6.4 years (Westland et al., 2013a). Moreover, 26\% of children with a SFK developed hypertension as early as 5 years of age, and $19 \%$ had proteinuria by 10 years of age (Westland et al., 2013a). In a small portion of children (6\%) GFR had begun to decline at a mean age of 6.4 years (Westland et al., 2013a). Kaplan-Meier analysis showed that the median age to develop kidney injury in children with a SFK was $\sim 15$ years (Westland et al., 2013a). Furthermore, children with ipsilateral CAKUT (34\% of all children with SFK) had a significantly higher incidence of kidney injury and a younger median age to develop kidney injury (12.8 years) compared with children without ipsilateral CAKUT (Westland et al., 2013a). In the KIMONO cohort a higher proportion of children with a SFK were boys $(65 \%)$, but no clear influence of gender on the development of kidney injury in SFK was found (Westland et al., 2013a; Westland and Schreuder, 2014).

In other studies the prognosis for children with a congenital SFK is suggested to be more favorable. Indeed, in a recent retrospective study of $\sim 300$ children prenatally diagnosed with a congenital SFK, only $3.9 \%$ had signs of kidney injury by a median age of 7 years (Marzuillo et al., 2017). Similarly, La Scola et al. (2016) observed that in a cohort of 146 children with a congenital SFK, only $5 \%$ of patients had hypertension at a mean 
TABLE 1 | Summary of clinical outcomes in patients with a congenital or early-acquired SFK.

\begin{tabular}{|c|c|c|c|c|c|c|}
\hline References & $\begin{array}{l}\text { Total number } \\
\text { of patients }\end{array}$ & $\begin{array}{l}\text { Gender } \\
\text { (M/F) }\end{array}$ & $\begin{array}{l}\text { Type of patients } \\
\text { included }\end{array}$ & Age (years) & Kidney injury & $\begin{array}{l}\text { Kidney length as a predictor } \\
\text { of kidney injury }\end{array}$ \\
\hline $\begin{array}{l}\text { Sanna-Cherchi } \\
\text { et al. (2009) }\end{array}$ & 71 & $52 / 19$ & $\begin{array}{l}\text { URA or empty renal } \\
\text { fossa upon imaging }\end{array}$ & $\begin{array}{l}\text { Mean age } 21 \\
(S D 13.6)\end{array}$ & $20-40 \%$ dialysis & NR \\
\hline Wang et al. (2010) & 65 & $36 / 29$ & $\begin{array}{l}48 \text { with URA } \\
17 \text { with severe } \\
\text { unilateral kidney } \\
\text { dysplasia }\end{array}$ & $\begin{array}{l}\text { Mean age } 36.7 \\
(S D 13.1)\end{array}$ & $\begin{array}{l}38.5 \% \text { reduced GFR } \\
\left(<60 \mathrm{ml} / \mathrm{min} / 1.73 \mathrm{~m}^{2}\right) \\
35.4 \% \text { proteinuria } \\
3 \% \text { dialysis } \\
36.9 \% \text { hypertension }\end{array}$ & $\begin{array}{l}\text { Kidney length }<120 \mathrm{~mm} \text { five-fold } \\
\text { greater risk reduced GFR }\end{array}$ \\
\hline Xu et al. (2019) & 118 & $62 / 56$ & URA & Median age 32 & $\begin{array}{l}25.4 \% \text { reduced GFR } \\
\left(<60 \mathrm{ml} / \mathrm{min} / 1.73 \mathrm{~m}^{2}\right) \\
43 \% \text { proteinuria } \\
32.2 \% \text { hypertension }\end{array}$ & $\begin{array}{l}\text { Patients with reduced GFR had a } \\
\text { shorter kidney length }\end{array}$ \\
\hline $\begin{array}{l}\text { Westland et al. } \\
(2011,2013 a)\end{array}$ & 407 & $265 / 142$ & $\begin{array}{l}223 \text { congenital SFK } \\
\text { (URA or MDCK) } \\
184 \text { early acquired } \\
\text { SFK }\end{array}$ & $\begin{array}{l}\text { Mean age } 6.4 \\
\text { (SD 5.7) } \\
\text { Mean age } 9.8 \\
\text { (SD 5.6) } \\
\text { Mean age } 4.9 \\
\text { (SD 5.4) }\end{array}$ & $\begin{array}{l}6 \% \text { reduced GFR } \\
\left(<60 \mathrm{ml} / \mathrm{min} / 1.73 \mathrm{~m}^{2}\right) \\
19 \% \text { proteinuria } \\
26 \% \text { hypertension }\end{array}$ & $\begin{array}{l}\text { Patients with a smaller SFK had a } \\
\text { greater incidence of kidney injury }\end{array}$ \\
\hline $\begin{array}{l}\text { Marzuillo et al. } \\
(2017,2019)\end{array}$ & 306 & $\begin{array}{c}\text { Not } \\
\text { specified }\end{array}$ & $\begin{array}{l}\text { Prenatally } \\
\text { diagnosed (URA } \\
\text { and MCDK) }\end{array}$ & $\begin{array}{l}\text { Mean age of kidney } \\
\text { injury onset } 8.2 \\
\text { (SD 5.6) }\end{array}$ & $\begin{array}{l}\text { 1.3\% reduced GFR } \\
\left(<90 \mathrm{ml} / \mathrm{min} / 1.73 \mathrm{~m}^{2}\right) \\
3.6 \% \text { proteinuria } \\
0.6 \% \text { hypertension }\end{array}$ & $\begin{array}{l}\text { In } 162 \text { of the } 306 \text { patients - } \\
\text { kidney length }<2 \text {-SDS in the } \\
\text { neonate period had a greater risk } \\
\text { of reduced GFR at } 15 \text { years of } \\
\text { age irrespective of postnatal } \\
\text { kidney hypertrophy }\end{array}$ \\
\hline $\begin{array}{l}\text { La Scola et al. } \\
\text { (2016) }\end{array}$ & 146 & $95 / 51$ & $\begin{array}{l}\text { URA, aplasia and } \\
\text { MCDK }\end{array}$ & $\begin{array}{l}\text { Median age } 2.2 \\
\text { Mean age } \\
5.6 \pm(4.4 \mathrm{SD}) \\
\text { Mean age } 12.2 \\
(3.1 \mathrm{SD})\end{array}$ & $\begin{array}{l}12 \% \text { reduced GFR } \\
\left(<90 \mathrm{ml} / \mathrm{min} / 1.73 \mathrm{~m}^{2}\right) \\
4 \% \text { proteinuria } \\
5 \% \text { hypertension }\end{array}$ & $\begin{array}{l}\text { Kidney length }<10 \% \text { expected } \\
\text { for a congenital SFK was the } \\
\text { strongest predictor of reduced } \\
\text { GFR by } 10 \text { years of age }\end{array}$ \\
\hline
\end{tabular}

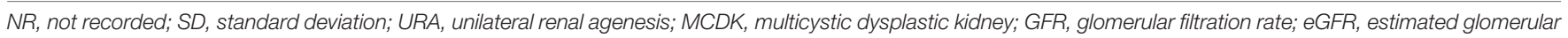
filtration rate.

age of 12 years and only $4 \%$ presented with proteinuria at a mean age of 6 years. However, a more recent study by La Scola et al. (2020) found that 33\% of SFK patients were hypertensive. This was based on ambulatory blood pressure measurement, which did show many cases of masked hypertension, similar to the KIMONO study (Westland et al., 2014; La Scola et al., 2020). The inconsistencies in cardiovascular and renal outcomes observed between studies may therefore reflect differences in study parameters such as inclusion criteria, selection bias, age of follow-up, and methods used to determine blood pressure, GFR and proteinuria. Despite these discrepancies, collectively in these studies it was shown that a congenital SFK does incur a greater predisposition for hypertension and kidney dysfunction later in life. However, there is a need for large long-term follow up studies beyond adolescence in individuals with a congenital SFK, as kidney dysfunction may develop later in life (Kolvek et al., 2014; Schreuder, 2017). It would be highly desirable to determine at diagnosis of SFK, which children have a poor prognosis and for this, accurate and sensitive biomarkers need to be identified.

\section{CONGENITAL SFK VERSUS EARLY ACQUIRED SFK}

Although data is limited, there appears to be differences in the renal outcomes associated with the origin of SFK. In the
KIMONO cohort those individuals with an early-acquired SFK had a greater incidence of kidney injury compared with those with a congenital SFK (Westland et al., 2011, 2013a). Consistent with these data, Abou Jaoudé et al. (2011) reported an $\sim 11 \%$ lower GFR in children with an early-acquired SFK $(n=53)$ compared with a congenital SFK $(n=44)$. A caveat to the finding of the KIMONO study is that those with an earlyacquired SFK were older at follow-up and had greater incidence of ipsilateral CAKUT compared with a congenital SFK (Westland et al., 2011, 2013a). As both older age and ipsilateral CAKUT were independent risk factors for kidney injury in the KIMONO cohort, these may account for the greater incidence of kidney injury in individuals with an early-acquired SFK.

\section{PRECLINICAL MODEL SYSTEMS}

Over the last 20 years our group has characterized the phenotype of a congenital SFK in sheep. This model is generated by removal of a kidney from the sheep fetus at gestation day 100, during the period of nephrogenesis in the sheep (term $=150$ days). There are various advantages of using the sheep as a model of SFK; (1) the development of the kidney in sheep is similar to that in humans with nephrogenesis reaching completion prior to birth in both species; (2) the size of the sheep and blood pressure and kidney function parameters are similar to that in humans making 
TABLE 2 | Comparison of the features in human and ovine fetal SFK.

\begin{tabular}{|c|c|c|c|c|c|c|}
\hline \multirow[t]{2}{*}{ Characteristics } & \multicolumn{6}{|c|}{ Congenital SFK } \\
\hline & Children & Age at onset & References & Ovine (males only) & $\begin{array}{l}\text { Age at } \\
\text { measurement }\end{array}$ & References \\
\hline Elevated blood pressure & $\sqrt{ }$ & Mean 4.9 years & Westland et al. (2013a) & $\sqrt{ }(7-15 \mathrm{mmHg})$ & 6 months & Singh et al. (2010) \\
\hline Reduced GFR & $\sqrt{ }$ & Mean 6.4 years & Westland et al. (2013a) & $\sqrt{ }(30 \%$ decrease $)$ & 6 months & Singh et al. (2010) \\
\hline Albuminuria & $\sqrt{ }$ & Mean 9.8 years & Westland et al. (2013a) & $\sqrt{ }$ & 6 months & Singh et al. (2009) \\
\hline Kidney hypertrophy & $\sqrt{ }$ & 20-36 weeks gestation & Van Vuuren et al. (2012b) & $\sqrt{ }$ & $\begin{array}{l}130 \text { days } \\
\text { gestation }\end{array}$ & $\begin{array}{l}\text { Douglas-Denton et al. } \\
\text { (2002) }\end{array}$ \\
\hline
\end{tabular}

GFR, glomerular filtration rate.

it an important preclinical model to examine the alterations in mechanisms regulating glomerular and tubular function and how these may underlie kidney injury in children with SFK (Table 2) (Moritz et al., 2008). Male and female rat pups that underwent unilateral nephrectomy in the first $24 \mathrm{~h}$ of postnatal life, a time when nephrogenesis is ongoing, have elevated blood pressure and lower GFR at the age of 20-22 weeks when compared with controls. In these uninephrectomized males, the elevation in blood pressure was greater than counterpart females and proteinuria and glomerular pathology was only observed in the males (Woods, 1999; Woods et al., 2001b). Similarly, in adult rats compensatory kidney hypertrophy of the remaining kidney 8 weeks after unilateral nephrectomy was two times greater in males compared with females and glomerular hypertrophy and damage were only observed in males but not in females (Mulroney et al., 1999). These observations suggest that SFK may increase disease severity in males more than females but these need to be confirmed in studies in humans.

\section{ADAPTATIONS TO A SFK}

It is well established that following a reduction in kidney mass whether it is congenital in origin or following unilateral nephrectomy in the child or the adult, there is marked compensatory kidney growth that is comprised of hypertrophy of both the kidney tubules and the glomerulus (Moritz et al., 2002, 2005; Singh et al., 2010; Fong et al., 2014; Chen et al., 2016; Wang et al., 2019; Zambaiti et al., 2019). In humans, compensatory kidney hypertrophy of the SFK begins as early as 20 weeks into gestation and by 36 weeks into gestation there is an $\sim 11 \%$ mean enlargement of the SFK compared with age matched controls (Van Vuuren et al., 2012b). Compensatory nephrogenesis is a characteristic adaptation to loss of kidney mass in utero but this is not always accompanied with compensatory increases in size of glomeruli. In a single human case study of a congenital SFK autopsied from a healthy 27 -year-old male, it was observed that the congenital SFK weighed twice as much and had twice as many nephrons as a single kidney from an age-matched control (Maluf, 1997). In a study in 26-week-old pigs born with a congenital SFK, an $80 \%$ increase in kidney weight and using stereology, a 50\% increase in nephron number in the SFK compared with a single control kidney was observed but individual glomerular volumes were similar to that of control (Van Vuuren et al., 2012a). In our ovine model of congenital SFK, fetal unilateral nephrectomy at 100 days of a 150 -day gestation, resulted in a $\sim 45 \%$ greater nephron number in the SFK compared with a single kidney of a sham operated control sheep at 130 days of gestation but individual glomerular volumes were lower in the SFK compared with control at this age (Douglas-Denton et al., 2002). In contrast, unilateral nephrectomy after birth has been shown to result in increase in glomerular size in the rat and the mouse (MacKay et al., 1990; Nyengaard, 1993; Mulroney et al., 1999; Woods, 1999; Woods et al., 2001b).

In addition to the compensatory increase in size of glomeruli, an increase in single nephron filtration (glomerular hyperfiltration), and increases in size and function of kidney tubules are also characteristic responses to loss of kidney mass (Layton et al., 2017). These include increases in the diameter and length of the proximal and distal tubules and density of sodium transporters, all of which facilitate a greater reabsorption of the increased filtered load (Celsi et al., 1986; Shirley and Walter, 1991; Pollock et al., 1992) (see Table 3). These have been reviewed in detail elsewhere (Fong et al., 2014; Lankadeva et al., 2014) and will be discussed briefly here. The increase in filtration and increase in function of the kidney tubules facilitates compensation of total GFR such that GFR of a single kidney is relatively the same as that of two kidneys. In landmark studies, originally in 5/6th nephrectomized rats, Brenner hypothesized that a reduction in kidney mass and thus nephron number result in adaptive increases in glomerular capillary pressure and glomerular hypertrophy facilitated glomerular hyperfiltration (increases in single nephron GFR; SNGFR), thus maintaining GFR within normal levels (Brenner et al., 1988). The age at which reduction in kidney mass occurs may strongly influence these compensatory responses with evidence that the compensation is more robust when kidney mass is reduced in the young compared with the adult (Larsson et al., 1980). Indeed, following donation of a kidney in adult humans, GFR recovers to $\sim 70 \%$ of pre-donation values (Krohn et al., 1966; Fesler et al., 2015). In contrast, in children ( $\sim 9$ years old) with a congenital or early-acquired SFK, GFR is preserved at a normal two-kidney level (100\% increase in GFR) (Abou Jaoudé et al., 2011). These observations are also supported by various studies in animals in which GFR and kidney size have been shown to increase more in the young after loss of a kidney compared with the adult (Galla et al., 1974; Larsson et al., 1980; Shirley and Walter, 1991) (see Table 3). 
TABLE 3 | Summary of compensatory adaptations to reduction in kidney mass.

\begin{tabular}{|c|c|c|c|c|c|}
\hline Species & Variable & Age at nephrectomy & Age at measurement & Outcomes & References \\
\hline \multirow[t]{2}{*}{ Rat } & Kidney weight & $\begin{array}{l}5 \text { days } \\
12 \text { days } \\
40 \text { days }\end{array}$ & 60 days old & $\begin{array}{l}72 \% \text { increase } \\
65 \% \text { increase } \\
36 \% \text { increase }\end{array}$ & Larsson et al. (1980) \\
\hline & & $\begin{array}{l}\text { Weanling } \\
\text { Young adult }\end{array}$ & $\begin{array}{l}4 \text { weeks post-unilateral } \\
\text { nephrectomy }\end{array}$ & $\begin{array}{l}144 \% \text { increase } \\
66 \% \text { increase }\end{array}$ & Galla et al. (1974) \\
\hline Rat & Glomerular volume & $\begin{array}{l}3 \text { days } \\
120 \text { days }\end{array}$ & 540 days & $\begin{array}{l}59 \% \text { increase } \\
20 \% \text { increase }\end{array}$ & Nyengaard (1993) \\
\hline Human & Total GFR & $\begin{array}{l}\text { Congenital } \\
\text { 20-60 years }\end{array}$ & $\begin{array}{l}9 \text { years old } \\
1-18 \text { days post-unilateral } \\
\text { nephrectomy }\end{array}$ & $\begin{array}{l}100 \% \text { increase } \\
70 \% \text { increase }\end{array}$ & $\begin{array}{l}\text { Abou Jaoudé et al. (2011) } \\
\text { Krohn et al. (1966) }\end{array}$ \\
\hline Rat & SNGFR & $\begin{array}{l}5 \text { days } \\
12 \text { days } \\
40 \text { days }\end{array}$ & 60 days old & $\begin{array}{l}115 \% \text { increase } \\
74 \% \text { increase } \\
47 \% \text { increase }\end{array}$ & Larsson et al. (1980) \\
\hline \multirow[t]{3}{*}{ Rat } & Proximal tubule length & Adult & $\begin{array}{l}\text { 2-4 weeks post-unilateral } \\
\text { nephrectomy }\end{array}$ & $35 \%$ increase & Hayslett et al. (1968) \\
\hline & & Adult & 4-6 post-unilateral nephrectomy & $71 \%$ increase & Pollock et al. (1992) \\
\hline & & 5 days old & 8 weeks & $160 \%$ & Celsi et al. (1986) \\
\hline \multirow[t]{2}{*}{ Rat } & Sodium reabsorption & Adult & $\begin{array}{l}\text { 4-6 weeks post-unilateral } \\
\text { nephrectomy }\end{array}$ & $50 \%$ increase & Pollock et al. (1992) \\
\hline & $\begin{array}{l}\text { Fractional proximal } \\
\text { reabsorption }\end{array}$ & Adult & $\begin{array}{l}30 \text { days post-unilateral } \\
\text { nephrectomy }\end{array}$ & $40 \%$ increase & Shirley and Walter (1991) \\
\hline Rat & Sodium transporter density & 5 days old & $\begin{array}{l}2 \text { weeks post-unilateral } \\
\text { nephrectomy }\end{array}$ & $168 \%$ increase & Celsi et al. (1986) \\
\hline
\end{tabular}

GFR, glomerular filtration rate; SNGFR, single nephron glomerular filtration rate.

\section{MECHANISMS FACILITATING ADAPTATIONS AND POTENTIATING KIDNEY DYSFUNCTION}

Increases in SNGFR facilitate adaptations compensating for loss of functioning nephrons but may also drive glomerular injury and contribute to progressive loss of kidney function (Brenner et al., 1988). Direct measurements of SNGFR are not possible in humans. Total GFR (the sum of all SNGFR) is currently the best prognostic indicator of kidney function in humans (Denic et al., 2017). SNGFR is influenced by various intrarenal mechanisms including glomerular capillary pressure, single nephron plasma flow, and tubuloglomerular feedback (TGF) (Blantz and Pelayo, 1984). The rise in SNGFR and glomerular capillary pressure following reduction in kidney mass has been associated with a reduction in afferent arteriole resistance and a right-ward shift in TGF (Müller-Suur et al., 1980; Salmond and Seney, 1991; Brown et al., 2011; Monu et al., 2018). It has been suggested that the right-ward shift results in blunting (resetting) of TGF where significantly higher fluid flow rates are required to cause a TGF mediated inhibition of SNGFR (Salmond and Seney, 1991). Thus, this resetting of TGF permits the increase in SNGFR and increase in glomerular capillary pressure in the remaining nephrons following nephron loss. In the rat, resetting of TGF $24 \mathrm{~h}$ after unilateral nephrectomy is mediated by enhanced connecting tubule glomerular feedback (a feedback system that influences afferent arteriole dilatation and is associated with epithelial sodium transporter; $\mathrm{ENaC}$ ) (Monu et al., 2018). This resetting of TGF also sustains the increase in glomerular capillary pressure observed following 5/6th and unilateral nephrectomy in the rat (Salmond and Seney, 1991). Since increases in glomerular capillary pressure can increase injury to the glomeruli it can be suggested that resetting of TGF may contribute to glomerular injury following loss of nephrons (Hostetter et al., 1981).

The age-related differences in glomerular hyperfiltration following a reduction in kidney mass may also be associated with differences in the glomerular hemodynamic responses driving glomerular hyperfiltration. In an adult rat model of 5/6th nephrectomy with a two and a half fold increase in SNGFR compared with controls, glomerular capillary pressure was only increased by $10 \%$ (Bidani et al., 1990). In contrast, guinea pigs subjected to unilateral nephrectomy at birth had a $30 \%$ increase in glomerular capillary pressure at 10-21 days of age (Chevalier, 1983). Interestingly, Celsi et al. (1989) observed that in 20-day-old rats, subjected to unilateral nephrectomy at 5 days of age, the two-fold increase in SNGFR was maintained by an increase in glomerular ultrafiltration pressure. However, by 60 days of age, this increase in SNGFR was maintained by both an increase in glomerular ultrafiltration pressure and increase in the filtering surface area (Celsi et al., 1989). These data suggest that a nephron loss in the young may favor a compensatory increase in glomerular capillary pressure to maintain GFR in the short-term (Celsi et al., 1989). In contrast, in a long-term study of glomerular hemodynamics in adult kidney donors, Lenihan et al. (2015) inferred that following kidney donation compensatory glomerular hyperfiltration was maintained predominantly by glomerular hypertrophy rather than an increase in glomerular capillary pressure. In a Japanese cohort consisting of normotensives, hypertensives and subjects with CKD, Kanzaki et al. (2017) reported that individuals with 
a history of CKD had half as many nephrons per kidney $(55 \%)$ as age matched normotensive individuals and $30 \%$ fewer nephrons per kidney than hypertensive individuals. In hypertensive subjects the volume of individual non-sclerosed glomeruli were greater than that of normotensive subjects but volume of non-sclerosed glomeruli was greatest in subjects with CKD. Estimated SNGFR was similar between subjects with hypertension and CKD but greater than that of normotensive subjects (Kanzaki et al., 2017). This suggested that increases in glomerular size supported GFR in the presence of low nephron number. Compensatory adaptations in size and function of kidney tubules facilitate a greater reabsorption of the increased filtered load (Celsi et al., 1986; Shirley and Walter, 1991; Pollock et al., 1992) (see Table 3). An increase in sodium transporter expression has been reported following reduction in kidney mass (Amaral et al., 2009; Kim et al., 2010; Singh et al., 2010). In our ovine model of congenital SFK, associated with elevated blood pressure and reduced GFR we have shown increased expression of $\mathrm{Na}+/ \mathrm{K}+$ ATPase $\beta 1, \mathrm{Na}+/ \mathrm{K}+$ ATPase $\gamma$ subunits and type 3 sodium hydrogen exchanger (NHE3) at 6 months of age (Singh et al., 2010). Moreover, following subtotal nephrectomy in the rat, at 4 weeks of age elevation in expression of $\mathrm{Na}$ $\mathrm{K}-2 \mathrm{Cl}$ cotransporter and $\mathrm{Na}-\mathrm{Cl}$ cotransporter was observed but these declined in expression by 12 weeks of age and this change in expression was associated with elevation in sodium excretion and increased kidney damage (Kim et al., 2010). This suggests there may be an association between changes in renal sodium transporter expression and severity of kidney injury. A greater reabsorption of certain components of the filtered load may also predispose the tubules to injury. For example, excessive proximal tubular reabsorption of filtered proteins or protein-bound substances in disease states with proteinuria has been shown to cause accumulation of inflammatory cells and macrophages in the tubular interstitium which may in turn enhance synthesis of extracellular matrix and proliferation of interstitial fibroblasts resulting in tubular injury (Eddy, 1994; Kees-Folts et al., 1994; Benigni and Remuzzi, 1996).

The underlying stimulus and mechanisms mediating kidney hypertrophy remain unclear. In the pig, compensatory nephrogenesis resulting in 50\% increase in nephron number was associated with 1.4-fold increase in the number of medullary papillae (Van Vuuren et al., 2012a). Using ultrasound, a similar 1.3 -fold increase in number of medullary papillae has also been observed in human fetuses with a congenital SFK (24 weeks gestation) compared with control fetuses (Snoek et al., 2018). Increase in number of medullary papillae indicates an increase in ureteric bud arborization, a process that determines final nephron complement suggesting that enhanced ureteric branching morphogenesis facilitates compensatory nephrogenesis in congenital SFK. These findings also suggest that the total nephron endowment in congenital SFK will amount to $\sim 70-75 \%$ rather than $50 \%$ of full nephron complement.

Other factors such as the nitric oxide system, the renal sympathetic nerves and the renin angiotensin system (RAS) have been implicated in the compensatory adaptations to reduction in kidney mass (Rojas-Canales et al., 2019). Nitric oxide (NO), released by the endothelium, is an important vasodilator of the vasculature. $\mathrm{NO}$ and the by-product L-citrulline, is formed from the precursor L-arginine by NO synthase (NOS), of which there are three isoforms, neuronal NOS (nNOS), inducible NOS (iNOS), and endothelial (eNOS) (Mount and Power, 2006). The expression of all three NOS isoforms have been observed in the kidney, and as such NO plays an important role in the modulation of renal glomerular hemodynamics, tubular function, fluid composition and volume and thus arterial pressure (Denton and Anderson, 1994; Mount and Power, 2006). The kidney hypertrophic response following unilateral nephrectomy in the rat has been suggested to be mediated by an elevation in production of $\mathrm{NO}$ and increase in renal blood flow (RBF) (Sigmon et al., 2004). The increased RBF following unilateral nephrectomy has also been proposed to increase the delivery of free amino acids to the remaining kidney stimulating the mTORC1 pathway which induces protein synthesis and cell proliferation leading to kidney hypertrophy (Chen et al., 2015). Blockade of NO with L-NAME prevents this increase in RBF and kidney hypertrophy (Sigmon et al., 2004). In endothelial nitric oxide (eNOS) knockout mice, an increase in kidney weight and increase in RBF were not observed after unilateral nephrectomy whereas in eNOS transgenic mice with targeted overexpression of eNOS to the vascular endothelium, an increase in compensatory kidney growth was observed after unilateral nephrectomy compared with the sham procedure (Nagasu et al., 2012). These collectively suggest that eNOS facilitated increase in RBF and enhanced expression of eNOS promotes compensatory kidney hypertrophy. Conversely, a reduction in NO has also been observed in animal models of reduced kidney mass and in humans with kidney failure and CKD (Blum et al., 1998; Schmidt and Baylis, 2000). At 15 weeks after 5/6th nephrectomy in rats, accompanying decreases in creatinine clearance, increases in proteinuria and glomerulosclerosis, total $\mathrm{NO}$ production and renal cortical nNOS were reduced (Tain et al., 2007). In our ovine model of SFK, we have demonstrated a reduced contribution of NO to kidney function in both aged and young sheep (Lankadeva et al., 2015; Singh et al., 2016). In sheep with congenital SFK, the renal responses to systemic blockade of NOS, via the administration of L-NAME, were attenuated compared with sham-operated sheep despite increased expression of renal eNOS (Lankadeva et al., 2015). The increase in expression of eNOS suggested that the kidneys could produce NO but further studies identified that increased oxidative stress maybe contributing to the reduction in bioavailability of $\mathrm{NO}$ and reducing the contribution of NO to kidney function in the sheep with SFK (Lankadeva et al., 2015). In addition to the reduced contribution of NO to kidney function, we have demonstrated reduced total urinary nitrate/nitrite levels in sheep with SFK (Singh et al., 2016). From these collective observations, we speculate that increases in eNOS may promote increases in RBF and promote the renal hypertrophic adaptation to SFK in the short-term but that reduction in bioavailability of NO, probably associated with increased oxidative stress may contribute to kidney dysfunction and hypertension in SFK.

Indirect evidence has also implicated renal sympathetic nerve activity (RSNA) in the kidney hypertrophic response (Furukawa et al., 1997). Following unilateral nephrectomy in 
the rat, relative mean RSNA increased by $78 \%$ at 28 days after nephrectomy, and this was associated with a $62 \%$ increase in kidney weight (Furukawa et al., 1997). Although we do not have direct evidence that elevations in RSNA drive compensatory hypertrophy, we do have evidence of renal hyperinnervation in our ovine model of SFK (Singh et al., 2017, 2019). In our recent studies, we have demonstrated sheep with a congenital SFK have a greater proportion of both sympathetic renal nerves and sensory renal nerves than sham animals demonstrating renal nerve hyperinnervation in SFK (Singh et al., 2019). The spontaneously hypertensive rat (SHR) model is a genetic model of hypertension and there is evidence that the kidneys of the SHR have less nephrons than normotensive Wistar Kyoto (WKY) control counterparts (Skov et al., 1994). In this model, accelerated development of renal innervation has been observed from newborn to postnatal week 6 compared with WKY controls and sympathetic innervation induced changes in kidney function in the neonate contribute to development of hypertension in SHR (Gattone et al., 1990; Grisk et al., 2002). Evidence for contribution of overactivity of the renal nerves to hypertension and kidney failure has also been documented in humans (Converse et al., 1992; Grassi et al., 2011; Symplicity, 2011; Krum et al., 2014; Mauriello et al., 2015). Collectively these findings suggest that renal hyperinnervation may have a role in promoting renal and cardiovascular dysfunction in models of reduced nephron number and as such have implications for SFK.

The RAS is a potent modulator of blood pressure, glomerular hemodynamics and fluid and electrolyte homeostasis and is also an important modulator of kidney development and maturation in the fetus and the neonate (Chen et al., 2004). Considerable evidence has also established the role of the RAS in the pathophysiology of hypertension and kidney disease (Hall et al., 1978; Johnson et al., 1992; Woods et al., 2001a; Grigore et al., 2007; Cuffe et al., 2016; Walton et al., 2017). Our ovine model of SFK is a model of low-renin hypertension, where we have reported lower levels of plasma renin in sheep with SFK from 6 months of age in both males and females (Moritz et al., 2002; Singh et al., 2009). This reduction in renin is likely a normal response to the rise in blood pressure that is observed in the sheep with SFK from 6 months of age (Singh et al., 2009). Additionally, we have also demonstrated that regulation of glomerular hemodynamics by the RAS is impaired in sheep with SFK, suggesting that this may potentially be a system that can be targeted to improve renal outcomes in SFK (Singh et al., 2011). Postnatal adaptive maturation of both blood pressure and glomerular filtration rate (GFR) is associated with the RAS (Robillard et al., 1983; Prevot et al., 2002; Vinturache and Smith, 2016). In conscious lambs, blood pressure is low at birth and plasma renin activity is elevated but during the first 3 months of post-natal maturation, plasma renin activity decreases as blood pressure increases (Monument and Smith, 2003; Velaphi et al., 2007). Additionally, in the early postnatal period in conscious lambs angiotensin II activation of AT1R regulates GFR and kidney injury associated with glomerular hyperfiltration and hypertrophy may be underpinned by RAS activation (Babić et al., 2007; Vinturache and Smith, 2016).

\section{BIOMARKERS AND AREAS OF FUTURE STUDY}

Classic biomarkers of CKD (albuminuria, reduced eGFR) occur at advanced stages of disease progression. Therefore, advancements in genetic testing, proteomics, metabolomics and imaging techniques may offer prognostic markers to predict CKD risk and disease progression before decline in kidney function occurs, allowing for the possibility of earlier intervention in SFK (Table 4) (Greenberg et al., 2018; Bennett et al., 2020).

\section{Nephron Number}

A deficiency of nephrons is a risk factor for kidney disease but the threshold of nephron number that predisposes to kidney disease is currently not known (Bertram et al., 2011). Harnessing this knowledge has been limited to-date given that nephron number cannot be determined in vivo in living subjects. Magnetic resonance imaging (MRI) in combination with cationized ferritin labeling of glomeruli using both ex vivo and in vivo approaches has been established as a reliable determinant of nephron number in rodents (Geraci et al., 2017; Baldelomar et al., 2018). Similarly, MRI in combination with cationized ferritin has been utilized to determine nephron number ex vivo in the whole kidney of the human (Beeman et al., 2014). Continued progress in this field resulting in determination of nephron number in the living human kidney will improve our ability to identify individuals at risk of developing kidney disease and track the progression of disease. This approach may also assist us in differentiating the long-term cardiovascular and renal outcomes between earlyacquired SFK and a congenital SFK. It is known that the kidney of the human does not have the capacity to form new nephrons after birth (Moritz and Wintour, 1999). Thus, the degree of nephron deficit may be more severe in an early-acquired SFK than a congenital SFK, and this may potentially underpin the greater risk for kidney injury in the early-acquired SFK group (Westland et al., 2014; Schreuder, 2017). The ability to determine a threshold for nephron number that predisposes to disease will enable is to devise better treatment strategies in individuals with different origins of SFK.

\section{Kidney Size}

In the absence of direct measurements of nephron number and limited information on validity of biomarkers for predicting kidney injury/disease in SFK, kidney size remains an important predictor of kidney injury in SFK. Inadequate kidney growth indicative of reduced nephron hyperplasia and/or hypertrophy has become an important predictive index of kidney dysfunction in children with a SFK (Westland et al., 2013a; Marzuillo et al., 2019; Poggiali et al., 2019). In a small cohort of Chinese adults with a congenital SFK, it was observed that individuals with a kidney length less than $120 \mathrm{~mm}$ had a five-fold greater risk for impaired GFR ( $<60 \mathrm{ml} / \mathrm{min} / 1.73 \mathrm{~m}^{2}$ ) (Wang et al., 2010). In the KIMONO cohort, it was demonstrated that a smaller SFK compared with a larger SFK was associated with a greater risk of developing kidney injury (Westland et al., 2013a). Similarly, La Scola et al. (2016) observed that a kidney length less than 
TABLE 4 | Current and next generation prognostic biomarkers for progression of kidney injury in children with SFK.

\begin{tabular}{|c|c|c|c|c|}
\hline Biomarker & Access & Cost & Prognostic utility & References \\
\hline $\begin{array}{l}\text { Kidney mass and kidney } \\
\text { length } \\
\text { Ultrasound }\end{array}$ & Freely accessible & Inexpensive & $\begin{array}{l}\text { Children with a smaller SFK are at a } \\
\text { greater risk for kidney injury }\end{array}$ & $\begin{array}{l}\text { Wang et al. (2010); } \\
\text { Westland et al. (2013a) }\end{array}$ \\
\hline $\begin{array}{l}\text { Nephron number } \\
\text { MRI }\end{array}$ & $\begin{array}{l}\text { Under development- } \\
\text { research testing in } \\
\text { animals only }\end{array}$ & Expensive & $\begin{array}{l}\text { May assist in differentiating those with a } \\
\text { reduced nephron number early in life }\end{array}$ & $\begin{array}{l}\text { Beeman et al. (2014); } \\
\text { Baldelomar et al. (2018) }\end{array}$ \\
\hline $\begin{array}{l}\text { Hyperfiltration } \\
\text { eGFR } \\
\text { SNGFR } \\
\text { Urinary prostaglandin E2 } \\
\text { Urinary nitrates }\end{array}$ & Freely accessible & Inexpensive & $\begin{array}{l}\text { Early changes in markers could predict } \\
\text { risk of kidney disease }\end{array}$ & $\begin{array}{l}\text { Westland et al. (2013a); } \\
\text { Singh et al. (2016); } \\
\text { Srivastava et al. (2020) }\end{array}$ \\
\hline $\begin{array}{l}\text { Plasma } \\
\text { Creatinine } \\
\text { Cystatin C } \\
\text { KIM-1 } \\
\text { MCP-1 }\end{array}$ & Freely accessible & Inexpensive & Kidney dysfunction and tubular injury & $\begin{array}{l}\text { Wasilewska et al. (2006); } \\
\text { Greenberg et al. (2020) }\end{array}$ \\
\hline $\begin{array}{l}\text { Urine } \\
\text { Creatinine } \\
\text { eGFR } \\
\text { Albuminuria } \\
N \text {-Acetyl-beta-D- } \\
\text { glucosaminidase (NAG) } \\
N \text {-Acetyl- } \beta \text {-hexosaminidase } \\
\text { (HEX) }\end{array}$ & Freely accessible & Inexpensive & $\begin{array}{l}\text { Glomerular and tubular injury } \\
\text { Predict risk of kidney injury }\end{array}$ & $\begin{array}{l}\text { Gadalean et al. (2013); } \\
\text { Westland et al. (2013a); } \\
\text { Taranta-Janusz et al. (2014) }\end{array}$ \\
\hline
\end{tabular}

MRI, magnetic resonance imaging; GFR, glomerular filtration rate; eGFR, estimated glomerular filtration rate; SNGFR, single nephron glomerular filtration rate; KIM-1, kidney injury molecular-1; MCP-1, monocyte chemoattractant protein-1.

$10 \%$ expected for a congenital SFK was the strongest predictor of reduced eGFR by 10 years of age. Conversely, Marzuillo et al. (2019) found that children who were diagnosed prenatally with SFK and had a greater than two standard deviation score (+2-SDS) kidney length in the neonatal period (within 60 days of life) were at a reduced risk of having lower eGFR at the age of 15 years compared with those with a kidney length less than +2 -SDS. Importantly, in this study, it was demonstrated that the risk for low eGFR in children with a kidney length $<2$-SDS presenting with postnatal compensatory kidney hypertrophy was similar to those with kidney length $<2$ SDS but without postnatal compensatory kidney hypertrophy. Based on these findings the authors concluded that nephron hyperplasia resulting in a greater kidney length likely provided protection against loss of kidney function in the long-term but nephron hypertrophy did not offer this protection (Marzuillo et al., 2019). The importance of kidney length as a predictor of kidney function in SFK has been further highlighted by a study by Wang et al. (2019) who demonstrated that every $1 \mathrm{~cm}$ increase in kidney length predicted a $7.8 \mathrm{ml} / \mathrm{min} / 1.73 \mathrm{~m}^{2}$ increase in GFR in children with a SFK. Together these studies suggest that insufficient compensatory kidney growth; perhaps lack of nephron hyperplasia more so than nephron hypertrophy, may increase the susceptibility to kidney dysfunction. However, it has been found that kidney size estimations in adults (with two kidneys) has poor predictive value in estimating nephron number, with only $5 \%$ of the variation in nephron number explained by the variation in kidney size (Bueters et al., 2013). This again highlights the need for determining nephron number together with kidney size in the living human, as these may be important predictive markers that can be utilized to identify those at an elevated risk for future kidney injury.

\section{Glomerular Injury}

Mechanisms pertaining to glomerulosclerosis associated with reduction in kidney mass are under investigation and implicate a role for podocyte loss in glomerular injury and dysfunction. During glomerular hypertrophy/hyperfiltration, associated increases in glomerular capillary pressure, exposes podocytes to stretch, tensile stress and fluid flow shear stress (FFSS), which may overtime decrease the integrity of the glomerular filtration barrier, resulting in podocyte damage and loss (Nagata et al., 1992; Srivastava et al., 2014b, 2017; Mallipattu and He, 2016). Following unilateral nephrectomy in young rats it has been observed that increases in SNGFR mediate a 1.5- to 2-fold increase in FFSS over podocytes and isolated glomeruli exposed to FFSS for $2 \mathrm{~h}$ have increased permeability to albumin indicating damage to the glomerular filtration barrier (Srivastava et al., 2014a,b). Additionally, in in vitro studies, applying FFSS to cultured podocytes has been demonstrated to increase levels of prostaglandins $\left(\mathrm{PGE}_{2}\right)$ from as early as $30 \mathrm{~min}$ after induction of FFSS and has been demonstrated to cause a reduction in the actin cytoskeleton of the podocytes (Srivastava et al., 2010). This suggests that $\mathrm{PGE}_{2}$ levels may serve as a marker of hyperfiltration mediated FFSS and glomerular filtration barrier dysfunction. In a recent study in children with SFK, it was shown that urinary $\mathrm{PGE}_{2}$ and albumin levels were elevated in children with a SFK $(n=57)$, at a mean age of 8.5 years, compared with children with two kidneys but it was also demonstrated that albuminuria was preceded by elevations in urinary $\mathrm{PGE}_{2}$ (Srivastava et al., 2020). 


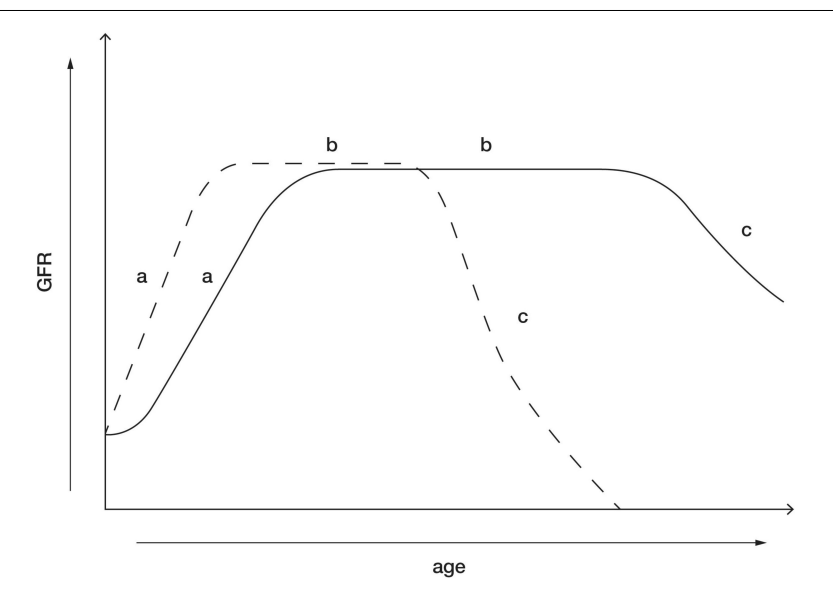

FIGURE 1 | Postnatal maturation of kidney function in healthy individuals with two kidneys (solid line) and maturation of kidney function in children with a congenital SFK (dotted line). (a) The phase after birth when GFR increases. This phase is likely enhanced in children who lose a kidney early in life. (b) GFR reaches its peak and is maintained within normal range for most of life in the absence of a "second hit" such as obesity, hypertension, and diabetes. This phase is likely to be shorter in children with SFK, possibly due to enhanced compensatory adaptations increasing the risk of kidney dysfunction. (c) Age-related decline in GFR in kidneys. This phase may be accelerated in individuals with SFK with kidney dysfunction and in some cases may result in kidney failure.

Therefore, elevated urinary $\mathrm{PGE}_{2}$ may be a potential biomarker for FFSS associated with hyperfiltration and may predict risk of kidney injury in children with a SFK (Srivastava et al., 2020). Moreover, since the increase in SNGFR after reduction in kidney mass are greater in the young compared with the adult (Table 2), these data suggest that adaptive glomerular hyperfiltration and associated increases in FFSS sustained from a younger age may cause degradation of the glomerular filtration barrier earlier in life, resulting in podocyte loss and may account for the greater incidence of kidney injury in children with a SFK compared with adult kidney donors (Figure 1).

\section{Tubular Injury}

In the $\mathrm{CKD}$ in Children (CKiD) multicenter cohort center, plasma concentrations of proximal tubular injury (kidney injury molecular-1, KIM-1), pro-inflammatory markers (monocyte chemoattractant protein-1, MCP-1) and receptors for proinflammatory markers (tumor necrosis factor alpha; TNFR1 and TNFR2) in the highest quartile identified children at greater risk of CKD progression compared with those with concentrations in the lowest quartile (Greenberg et al., 2020). Gadalean et al. (2013) observed that in adult patients with an acquired and congenital SFK there was a $\sim 52-60 \%$ increase in urinary $N$-acetyl-beta-D-glucosaminidase, a marker of proximal tubule dysfunction. Similarly, in children with both a congenital SFK and acquired SFK, urinary $N$-acetyl- $\beta$-hexosaminidase (HEX), an indicator of proximal tubular damage, was elevated compared with age-matched healthy individuals (Taranta-Janusz et al., 2014). Moreover, estimated urinary HEX was a good diagnostic indicator of kidney injury (presence of albuminuria) in children with a SFK (Taranta-Janusz et al., 2014). Interestingly, it has been observed that children with URA excrete higher levels of $\beta 2$-microglobulin indicating proximal tubular damage, compared with children with an early-acquired SFK (unilateral nephrectomy due to Wilm's tumor) (Stefanowicz et al., 2012). These data indicate that a greater reabsorption of filtered load may increase tubulointerstitial inflammation resulting in tubular injury and that urinary markers of proximal tubular injury are elevated in children with a SFK and may be diagnostic indicators of kidney damage.

\section{Endothelial Dysfunction}

Asymmetrical dimethylarginine (ADMA), a competitive NOS inhibitor that causes reduced NO production, and its enantiomer symmetric dimethylarginine (SDMA) have been observed to accumulate in the early stages of $\mathrm{CKD}$ and kidney failure (Zoccali et al., 2001; Kielstein et al., 2002; Fleck et al., 2003; Busch et al., 2006; Brooks et al., 2008; El-Sadek et al., 2016). Ravani et al. (2005) demonstrated that plasma ADMA is a strong independent risk factor for progression to kidney failure and death in patients with CKD. Brooks et al. (2008) observed reduced plasma arginine and elevated ADMA and SDMA in pediatric/adolescent CKD (stage 2-3) patients, with SDMA demonstrated to be a strong indicator of reduced GFR. Importantly, in a small cohort of 51 children with a SFK at a mean age of $\sim 10$ years, plasma SDMA was significantly elevated and negatively correlated with GFR, suggesting that plasma SDMA may serve as a marker of endothelial dysfunction in children with a SFK (Taranta-Janusz et al., 2012).

\section{POTENTIAL TREATMENT OPTIONS}

\section{Increasing NO Bioavailability}

Nitric oxide has an important role in the renal hypertrophic and hemodynamic adaptation in SFK. However, reductions in bioavailability of NO may be associated with increases in oxidative stress in SFK (Lankadeva et al., 2015). Increasing bioavailability of NO by dietary supplementation with L-arginine in rats subjected to subtotal nephrectomy has been shown to prevent glomerular hypertension and preserve kidney function and has been shown to prevent glomerular hyperfiltration and proteinuria in diabetic rats (Reyes et al., 1993; Katoh et al., 1994). In hypertensive patients with micro-vascular angina, oral L-arginine treatment for 4 weeks was shown to improve systolic blood pressure and quality of life (Palloshi et al., 2004). The therapeutic value of oral-L-arginine treatment needs to be further explored in SFK.

\section{Renal Denervation}

In our recent studies, we have demonstrated that renal denervation in sheep with SFK resulted in long-term lowering of blood pressure, improvement of GFR and reduction in albuminuria compared with animals with SFK that underwent a sham denervation procedure (Singh et al., 2019). This suggests that hyperinnervation of the renal nerves may potentially be contributing to the elevation in blood pressure and kidney disease 
in SFK and has implications for children with SFK. A role for renal sympathetic overactivity in promoting hypertension is also evident in other models of reduced kidney mass, such as the developmental programming models (maternal glucocorticoid exposure) and genetic models (SHR) (Gattone et al., 1990; Alexander et al., 2005; Dagan et al., 2008; Kett and Denton, 2011; Mansuri et al., 2017). Prenatal exposure to dexamethasone is well known to cause a reduction in nephron number and elevation in blood pressure in studies in various species (Singh et al., 2012). In the rat, the elevation in blood pressure in the offspring that results from prenatal exposure to dexamethasone was ameliorated by renal denervation (Dagan et al., 2008). Moreover, renal denervation in SHR reduces blood pressure longterm and attenuates the kidney injury associated with proteinuria and glomerulosclerosis (Wang et al., 2018). Combined with clinical evidence of the association of CKD with sympathetic hyperinnervation, markers of sympathetic activity in young children may serve as a prognostic indicator of future disease severity in children with a SFK. Indeed, noradrenaline can be detected in urine, the levels of which have previously been shown to correlate with the level of sympathetic activity (Lappe et al., 1982). Further studies examining the role of RSNA in models of reduced kidney mass are warranted in the future and may provide evidence to advance this to clinical studies.

\section{RAS Blockade}

Pharmacological inhibition of the RAS with either an ACEi or an ARB may be effective in preventing hyperfiltrationmediated injury associated with SFK (Lewis et al., 1993; Romero et al., 2015). Indeed, in patients with diabetic nephropathy, in which hyperfiltration is a hallmark response, ACE inhibition prevents the decline in kidney function independent of its antihypertensive effects (Lewis et al., 1993). There is growing evidence that pharmacologically targeting the RAS during early postnatal maturation may provide long-lasting cardiovascular and renal benefits. Brief and early treatment with ACEi from 6 to 10 weeks of age in the SHR reduced blood pressure by 20-30 mm Hg until approximately 82 weeks of age (Harrap et al., 1994). Consistently, in models of maternal low protein diet or calorie restriction, treatment with ACEi or ARB's for a brief period early in postnatal life prevented hypertension into early adulthood (Sherman and Langley-Evans, 1998, 2000; Manning and Vehaskari, 2005; Hsu et al., 2015). Interestingly, Hsu et al. (2015) observed that rat offspring exposed to maternal calorie restriction but treated with aliskiren, a renin inhibitor, from 2 to 4 weeks of age did not develop hypertension at 12 weeks of age. These improvements were associated with a reduction in angiotensinogen expression and improved bioavailability of NO. This suggests that the balance between NO bioavailability and RAS activity may influence regulation of blood pressure. Blockade of RAS in children with CKD and hypertension not only improves control of blood pressure but improves renal outcomes as well. Indeed, in the ESCAPE trial in children with CKD and hypertension, who received a high dose of an ACEi, blood pressure control was intensified and was associated with a $35 \%$ reduction in relative risk of loss of kidney function (50\%) or kidney failure within the 5-year follow-up (Wuhl et al., 2009). In addition, a higher degree of early anti-proteinuric effects of ACEi predicted a lower risk of renal functional decline in these children with CKD (Van Den Belt et al., 2018). However, following 3 years of ongoing ACEi the proteinuria rebounded in the ESCAPE trial (Wuhl et al., 2009). The improvements in kidney outcomes associated with RAS blockade maybe associated with RAS control of glomerular hemodynamics. Anderson et al. (1985) observed that treatment with ACEi in a rat model of 5/6th nephrectomy controlled systemic and glomerular capillary pressure via efferent arteriole dilation which in turn prevented proteinuria and glomerular injury. Together this evidence indicates that RAS inhibition may prevent the rise in blood pressure and also alter glomerular hemodynamics in a manner that can reduce kidney injury in children with SFK.

\section{CONCLUSION}

Children born with a SFK are at a greater risk for developing hypertension, kidney injury and CKD. This predisposition is likely associated with the greater degree of compensatory adaptations early in life that include compensatory increases in GFR, glomerular size and function and size of the kidney tubules following a reduction in kidney mass in young children or in fetuses. Our extensive studies in an ovine model of congenital SFK, along with work in other models of a reduction in kidney mass have demonstrated that alterations in the renal sympathetic nerves, the renal RAS and the nitric oxide system may be strong contributing factors to the development of disease associated with SFK. These studies have provided the foundation suggesting that these systems can potentially be targeted in SFK to reduce the progression of disease. Currently, common prognostic indicators such as hypertension, proteinuria and reduced GFR are available to detect kidney injury/failure in children with a SFK, but these emerge at later stages of disease progression. Emerging indicators such as kidney length and urinary markers of tubular injury and glomerular hyperfiltration may be beneficial in identifying those at an elevated risk of kidney injury earlier in life. However, markers that distinguish those at an elevated risk of kidney injury as opposed to those with a lower risk, before overt kidney injury occur, are needed. Ideally, this would occur during the neonatal period when the SFK was identified.

\section{AUTHOR CONTRIBUTIONS}

All authors assisted with drafting the manuscript, searching the literature and proofreading the document. All authors contributed to the article and approved the submitted version.

\section{FUNDING}

MS was supported by a grant from The Netherlands Organization for Health Research and Development (ZonMW Vidi 016.156.454). KD (APP1041844) and KM (APP1078164) are supported by Senior Research Fellowships from the National Health and Medical Council of Australia. 


\section{REFERENCES}

Abou Jaoudé, P., Dubourg, L., Bacchetta, J., Berthiller, J., Ranchin, B., and Cochat, P. (2011). Congenital versus acquired solitary kidney: is the difference relevant? Nephrol. Dial. Transpl. 26, 2188-2194. doi: 10.1093/ndt/ gfq659

Alexander, B. T., Hendon, A. E., Ferril, G., and Dwyer, T. M. (2005). Renal denervation abolishes hypertension in low-birth-weight offspring from pregnant rats with reduced uterine perfusion. Hypertension 45, 754-758. doi: 10.1161/01.hyp.0000153319.20340.2a

Amaral, J. S., Pinho, M. J., and Soares-Da-Silva, P. (2009). Regulation of amino acid transporters in the rat remnant kidney. Nephrol. Dial. Transpl. 24, 2058-2067. doi: $10.1093 / \mathrm{ndt} / \mathrm{gfn} 752$

Anderson, S., Meyer, T. W., Rennke, H. G., and Brenner, B. M. (1985). Control of glomerular hypertension limits glomerular injury in rats with reduced renal mass. J. Clin. Invest. 76, 612-619. doi: 10.1172/jci11 2013

Argueso, L. R., Ritchey, M. L., Boyle, E. T. Jr., Milliner, D. S., Bergstralh, E. J., and Kramer, S. A. (1992). Prognosis of patients with unilateral renal agenesis. Pediatr. Nephrol. 6, 412-416. doi: 10.1007/bf00873996

Babić, N., Huskić, J., and Nakas-Ićindić, E. (2007). Angiotensin converting enzyme activity in compensatory renal hypertrophy. Bosnian J. Basic Med. Sci. 7, 79-83. doi: 10.17305/bjbms.2007.3098

Baldelomar, E. J., Charlton, J. R., Beeman, S. C., and Bennett, K. M. (2018). Measuring rat kidney glomerular number and size in vivo with MRI. Am.J .Physiol Renal Physiol. 314, F399-F406.

Becherucci, F., Roperto, R. M., Materassi, M., and Romagnani, P. (2016). Chronic kidney disease in children. Clin. Kidney J. 9, 583-591.

Beeman, S. C., Cullen-Mcewen, L. A., Puelles, V. G., Zhang, M., Wu, T., Baldelomar, E. J., et al. (2014). MRI-based glomerular morphology and pathology in whole human kidneys. Am. J. Physiol. Renal Physiol. 306, F1381F1390.

Benigni, A., and Remuzzi, G. (1996). Glomerular protein trafficking and progression of renal disease to terminal uremia. Semin. Nephrol. 16, 151-159.

Bennett, K. M., Baldelomar, E. J., Morozov, D., Chevalier, R. L., and Charlton, J. R. (2020). New imaging tools to measure nephron number : opportunities for developmental nephrology. J. Dev. Origin. Health Dis. [Epub ahead of print].

Bertram, J. F., Douglas-Denton, R. N., Diouf, B., Hughson, M. D., and Hoy, W. E. (2011). Human nephron number: implications for health and disease. Pediatr. Nephrol. 26, 1529-1533. doi: 10.1007/s00467-011-1843-8

Bidani, A. K., Mitchell, K. D., Schwartz, M. M., Navar, L. G., and Lewis, E. J. (1990). Absence of glomerular injury or nephron loss in a normotensive rat remnant kidney model. Kidney Int. 38, 28-38. doi: 10.1038/ki.1990.163

Blantz, R. C., and Pelayo, J. C. (1984). A functional role for the tubuloglomerular feedback mechanism. Kidney Int. 25, 739-746. doi: 10.1038/ki.1984.84

Blum, M., Yachnin, T., Wollman, Y., Chernihovsky, T., Peer, G., Grosskopf, I., et al. (1998). Low nitric oxide production in patients with chronic renal failure. Nephron 79, 265-268. doi: 10.1159/000045047

Brenner, B. M., Garcia, D. L., and Anderson, S. (1988). Glomeruli and blood pressure. Less of one, more the other? Am. J. Hypertens. 1, 335-347. doi: 10.1093/ajh/1.4.335

Brooks, E. R., Langman, C. B., Wang, S., Price, H. E., Hodges, A. L., Darling, L., et al. (2008). Methylated arginine derivatives in children and adolescents with chronic kidney disease. Pediatr. Nephrol. 24:129. doi: 10.1007/s00467-0080972-1

Brown, R. D., Turner, A. J., Carlström, M., Persson, A. E., and Gibson, K. J. (2011). Tubuloglomerular feedback response in the prenatal and postnatal ovine kidney. Am. J. Physiol. Renal Physiol. 300, F1368-F1374.

Bueters, R. R., Van De Kar, N. C., and Schreuder, M. F. (2013). Adult renal size is not a suitable marker for nephron numbers: an individual patient data meta-analysis. Kidney Blood Press. Res. 37, 540-546. doi: 10.1159/000355734

Busch, M., Fleck, C., Wolf, G., and Stein, G. (2006). Asymmetrical (ADMA) and symmetrical dimethylarginine (SDMA) as potential risk factors for cardiovascular and renal outcome in chronic kidney disease - possible candidates for paradoxical epidemiology? Amino Acids 30, 225-232. doi: 10. 1007/s00726-005-0268-8
Celsi, G., Larsson, L., and Aperia, A. (1986). Proximal tubular reabsorption and Na-K-ATPase activity in remnant kidney of young rats. Am. J. Physiol. 251, F588-F593.

Celsi, G., Larsson, L., Seri, I., Savin, V., and Aperia, A. (1989). Glomerular adaptation in uninephrectomized young rats. Pediatr. Nephrol. 3, 280-285. doi: $10.1007 /$ bf00858530

Chen, J. K., Nagai, K., Chen, J., Plieth, D., Hino, M., Xu, J., et al. (2015). Phosphatidylinositol 3-kinase signaling determines kidney size. J. Clin. Invest. 125, 2429-2444. doi: 10.1172/jci78945

Chen, K. W., Wu, M. W., Chen, Z., Tai, B. C., Goh, Y. S., Lata, R., et al. (2016). Compensatory hypertrophy after living donor nephrectomy. Transplant. Proc. 48, 716-719. doi: 10.1016/j.transproceed.2015. 12.082

Chen, Y., Lasaitiene, D., and Friberg, P. (2004). The renin-angiotensin system in kidney development. Acta Physiol. Scand. 181, 529-535.

Chevalier, R. L. (1983). Reduced renal mass in early postnatal development. Neonatology 44, 158-165. doi: 10.1159/000241710

Converse, R. L. Jr., Jacobsen, T. N., Toto, R. D., Jost, C. M., Cosentino, F., Fouad-Tarazi, F., et al. (1992). Sympathetic overactivity in patients with chronic renal failure. N. Engl. J. Med. 327, 1912-1918. doi: 10.1056/nejm199212313 272704

Cuffe, J. S. M., Burgess, D. J., O'sullivan, L., Singh, R. R., and Moritz, K. M. (2016). Maternal corticosterone exposure in the mouse programs sex-specific renal adaptations in the renin-angiotensin-aldosterone system in 6-month offspring. Physiol. Rep. 4:e12754. doi: 10.14814/phy2.12754

Dagan, A., Kwon, H. M., Dwarakanath, V., and Baum, M. (2008). Effect of renal denervation on prenatal programming of hypertension and renal tubular transporter abundance. Am. J. Physiol. Renal Physiol. 295, F29-F34.

Denic, A., Mathew, J., Lerman, L. O., Lieske, J. C., Larson, J. J., Alexander, M. P., et al. (2017). Single-nephron glomerular filtration rate in healthy adults. N. Engl. J. Med. 376, 2349-2357.

Denton, K. M., and Anderson, W. P. (1994). Intrarenal haemodynamic and glomerular responses to inhibition of nitric oxide formation in rabbits. J. Physiol. 475, 159-167. doi: 10.1113/jphysiol.1994.sp020057

Douglas-Denton, R., Moritz, K. M., Bertram, J. F., and Wintour, E. M. (2002). Compensatory renal growth after unilateral nephrectomy in the ovine fetus. J. Am. Soc. Nephrol. 13, 406-410.

Eddy, A. A. (1994). Experimental insights into the tubulointerstitial disease accompanying primary glomerular lesions. J. Am. Soc. Nephrol. 5, 1273-1287.

El-Sadek, A. E., Behery, E. G., Azab, A. A., Kamal, N. M., Salama, M. A., Abdulghany, W. E., et al. (2016). Arginine dimethylation products in pediatric patients with chronic kidney disease. Ann. Med. Surg. 9, 22-27. doi: 10.1016/j. amsu.2016.05.017

Fehrman-Ekholm, I., Duner, F., Brink, B., Tyden, G., and Elinder, C. G. (2001). No evidence of accelerated loss of kidney function in living kidney donors: results from a cross-sectional follow-up. Transplantation 72, 444-449. doi: 10.1097/00007890-200108150-00015

Fesler, P., Mourad, G., Cailar, G. D., Ribstein, J., and Mimran, A. (2015). Arterial stiffness: an independent determinant of adaptive glomerular hyperfiltration after kidney donation. Am. J. Physiol. Renal Physiol. 308, F567-F571.

Fleck, C., Schweitzer, F., Karge, E., Busch, M., and Stein, G. (2003). Serum concentrations of asymmetric (ADMA) and symmetric (SDMA) dimethylarginine in patients with chronic kidney diseases. Clin. Chim. Acta 336, 1-12. doi: 10.1016/s0009-8981(03)00338-3

Fong, D., Denton, K. M., Moritz, K. M., Evans, R., and Singh, R. R. (2014). Compensatory responses to nephron deficiency: adaptive or maladaptive? Nephrology 19, 119-128. doi: 10.1111/nep.12198

Furukawa, K., Ninomiya, I., Shimizu, J., Wada, T., and Matsuura, Y. (1997). Renal sympathetic nerve activity and the weight of the remaining kidney in unilateral nephrectomized rats. J. Auton. Nerv. Syst. 63, 91-100. doi: 10.1016/s01651838(96)00137-3

Gadalean, F., Kaycsa, A., Gluhovschi, G., Velciov, S., Gluhovschi, C., Bob, F., et al. (2013). Is the urinary biomarkers assessment a non-invasive approach to tubular lesions of the solitary kidney? Renal Failure 35, 1358-1364. doi: 10.3109/0886022x.2013.828367 
Galla, J. H., Klein-Robbenhaar, T., and Hayslett, J. P. (1974). Influence of age on the compensatory response in growth and function to unilateral nephrectomy. Yale J. Biol. Med. 47, 218-226.

Gattone, V. H., Evan, A. P., Overhage, J. M., and Severs, W. B. (1990). Developing renal innervation in the spontaneously hypertensive rat: evidence for a role of the sympathetic nervous system in renal damage. J. Hypertens. 8:423. doi: 10.1097/00004872-199005000-00005

Geraci, S., Chacon-Caldera, J., Cullen-Mcewen, L., Schad, L. R., Sticht, C., Puelles, V. G., et al. (2017). Combining new tools to assess renal function and morphology: a holistic approach to study the effects of aging and a congenital nephron deficit. Am. J. Physiol. Renal Physiol. 313, F576-F584.

Grassi, G., Quarti-Trevano, F., Seravalle, G., Arenare, F., Volpe, M., Furiani, S., et al. (2011). Early sympathetic activation in the initial clinical stages of chronic renal failure. Hypertension 57, 846-851. doi: 10.1161/hypertensionaha.110. 164780

Greenberg, J. H., Abraham, A. G., Xu, Y., Schelling, J. R., Feldman, H. I., Sabbisetti, V. S., et al. (2020). Plasma biomarkers of tubular injury and inflammation are associated with chronic kidney disease progression in children. J. Am. Soc. Nephrol. 31, 1067-1077.

Greenberg, J. H., Kakajiwala, A., Parikh, C. R., and Furth, S. (2018). Emerging biomarkers of chronic kidney disease in children. Pediatr. Nephrol. 33, 925-933. doi: 10.1007/s00467-017-3701-9

Grigore, D., Ojeda, N. B., Robertson, E. B., Dawson, A. S., Huffman, C. A., Bourassa, E. A., et al. (2007). Placental insufficiency results in temporal alterations in the renin angiotensin system in male hypertensive growth restricted offspring. Am. J. Physiol. Regul. Integr. Comp. Physiol. 293, R804-R811.

Grisk, O., Rose, H.-J., Lorenz, G., and Rettig, R. (2002). Sympathetic-renal interaction in chronic arterial pressure control. Am. J. Physiol. Regul. Integr. Comp. Physiol. 283, R441-R450.

Hall, J. E., Guyton, A. C., Salgado, H. C., Mccaa, R. E., and Balfe, J. W. (1978). Renal hemodynamics in acute and chronic angiotensin II hypertension. Am. J. Physiol. Renal Physiol. 235, F174-F179.

Harrap, S. B., Mirakian, C., Datodi, S. R., and Lever, A. F. (1994). Blood pressure and lifespan following brief ACE inhibitor treatment in young spontaneously hypertensive rats. Clin. Exp. Pharmacol. Physiol. 21, 125-127. doi: 10.1111/j. 1440-1681.1994.tb02479.x

Hayslett, J. P., Kashgarian, M., and Epstein, F. H. (1968). Functional correlates of compensatory renal hypertrophy. J. Clin. Investig. 47, 774-782. doi: 10.1172/ jci105772

Hostetter, T. H., Olson, J. L., Rennke, H. G., Venkatachalam, M. A., and Brenner, B. M. (1981). Hyperfiltration in remnant nephrons: a potentially adverse response to renal ablation. Am. J. Physiol. 241, F85-F93.

Hsu, C. N., Lee, C. T., Huang, L. T., and Tain, Y. L. (2015). Aliskiren in early postnatal life prevents hypertension and reduces asymmetric dimethylarginine in offspring exposed to maternal caloric restriction. J. Renin. Angiotensin. Aldosterone Syst. 16, 506-513. doi: 10.1177/147032031351 4123

Ibrahim, H. N., Foley, R., Tan, L., Rogers, T., Bailey, R. F., Guo, H., et al. (2009). Long-term consequences of kidney donation. N. Engl. J. Med. 360, 459-469.

Johnson, R. J., Alpers, C. E., Yoshimura, A., Lombardi, D., Pritzl, P., Floege, J., et al. (1992). Renal injury from angiotensin II-mediated hypertension. Hypertension 19, 464-474. doi: 10.1161/01.hyp.19.5.464

Kanzaki, G., Puelles, V. G., Cullen-Mcewen, L. A., Hoy, W. E., Okabayashi, Y., Tsuboi, N., et al. (2017). New insights on glomerular hyperfiltration: a Japanese autopsy study. JCI Insight 2:e94334.

Kasiske, B. L., Ma, J. Z., Louis, T. A., and Swan, S. K. (1995). Long-term effects of reduced renal mass in humans. Kidney Int. 48, 814-819. doi: 10.1038/ki. 1995.355

Katoh, T., Takahashi, K., Klahr, S., Reyes, A. A., and Badr, K. F. (1994). Dietary supplementation with L-arginine ameliorates glomerular hypertension in rats with subtotal nephrectomy. J. Am. Soc. Nephrol. 4, 1690-1694.

Kees-Folts, D., Sadow, J. L., and Schreiner, G. F. (1994). Tubular catabolism of albumin is associated with the release of an inflammatory lipid. Kidney Int. 45, 1697-1709. doi: 10.1038/ki.1994.222

Kett, M. M., and Denton, K. M. (2011). Renal programming: cause for concern? Am. J. Physiol. Regul. Integr. Comp. Physiol. 300, R791-R803.
Kielstein, J. T., Boger, R. H., Bode-Boger, S. M., Frolich, J. C., Haller, H., Ritz, E., et al. (2002). Marked increase of asymmetric dimethylarginine in patients with incipient primary chronic renal disease. J. Am. Soc. Nephrol. 13, 170-176.

Kim, S., Heo, N. J., Jung, J. Y., Son, M. J., Jang, H. R., Lee, J. W., et al. (2010). Changes in the sodium and potassium transporters in the course of chronic renal failure. Nephron Physiol. 115, 31-41.

Kolvek, G., Podracka, L., Rosenberger, J., Stewart, R. E., Van Dijk, J. P., and Reijneveld, S. A. (2014). Solitary functioning kidney in children - a follow-up study. Kidney Blood Press. Res. 39, 272-278. doi: 10.1159/000355804

Krohn, A. G., Ogden, D. A., and Holmes, J. H. (1966). Renal function in 29 healthy adults before and after nephrectomy. JAMA 196, 322-324. doi: 10.1001/jama. 196.4.322

Krum, H., Schlaich, M. P., Sobotka, P. A., Böhm, M., Mahfoud, F., Rocha-Singh, K., et al. (2014). Percutaneous renal denervation in patients with treatmentresistant hypertension: final 3-year report of the Symplicity HTN-1 study. Lancet 383, 622-629. doi: 10.1016/s0140-6736(13)62192-3

Kummer, S., Von Gersdorff, G., Kemper, M. J., and Oh, J. (2012). The influence of gender and sexual hormones on incidence and outcome of chronic kidney disease. Pediatr. Nephrol. 27, 1213-1219. doi: 10.1007/s00467-011-1963-1

La Scola, C., Ammenti, A., Puccio, G., Lega, M. V., De Mutiis, C., Guiducci, C., et al. (2016). Congenital solitary kidney in children: size matters. J. Urol. 196, 1250-1256. doi: 10.1016/j.juro.2016.03.173

La Scola, C., Marra, G., Ammenti, A., Pasini, A., Taroni, F., Bertulli, C., et al. (2020). Born with a solitary kidney: at risk of hypertension. Pediatr. Nephrol. [Epub ahead of print].

Lankadeva, Y. R., Singh, R. R., Moritz, K. M., Parkington, H. C., Denton, K. M., and Tare, M. (2015). Renal dysfunction is associated with a reduced contribution of nitric oxide and enhanced vasoconstriction after a congenital renal mass reduction in sheep. Circulation 131, 280-288. doi: 10.1161/circulationaha.114. 013930

Lankadeva, Y. R., Singh, R. R., Tare, M., Moritz, K. M., and Denton, K. M. (2014). Loss of a kidney during fetal life: long-term consequences and lessons learned. Am. J. Physiol. Renal Physiol. 306, F791-F800.

Lappe, R. W., Henry, D. P., and Willis, L. R. (1982). Contribution of renal sympathetic nerves to the urinary excretion of norepinephrine. Can. J. Physiol. Pharmacol. 60, 1067-1072. doi: 10.1139/y82-153

Larsson, L., Aperia, A., and Wilton, P. (1980). Effect of normal development on compensatory renal growth. Kidney Int. 18, 29-35. doi: 10.1038/ki.1980.107

Layton, A. T., Edwards, A., and Vallon, V. (2017). Adaptive changes in GFR, tubular morphology, and transport in subtotal nephrectomized kidneys: modeling and analysis. Am. J. Physiol. Renal Physiol. 313, F199-F209.

Lenihan, C. R., Busque, S., Derby, G., Blouch, K., Myers, B. D., and Tan, J. C. (2015). Longitudinal study of living kidney donor glomerular dynamics after nephrectomy. J. Clin. Investig. 125, 1311-1318. doi: 10.1172/jci78885

Lewis, E. J., Hunsicker, L. G., Bain, R. P., and Rohde, R. D. (1993). The effect of angiotensin-converting-enzyme inhibition on diabetic nephropathy. N. Engl. J. Med. 329, 1456-1462.

Li, Z. Y., Chen, Y. M., Qiu, L. Q., Chen, D. Q., Hu, C. G., Xu, J. Y., et al. (2019). Prevalence, types, and malformations in congenital anomalies of the kidney and urinary tract in newborns: a retrospective hospital-based study. Ital. J. Pediatr. 45:50.

MacKay, K., Striker, L. J., Stauffer, J. W., Agodoa, L. Y., and Striker, G. E. (1990). Relationship of glomerular hypertrophy and sclerosis: studies in SV40 transgenic mice. Kidney Int. 37, 741-748. doi: 10.1038/ki.1990.41

Mallipattu, S. K., and He, J. C. (2016). The podocyte as a direct target for treatment of glomerular disease? Am. J. Physiol. Renal Physiol. 311, F46-F51.

Maluf, N. S. R. (1997). On the enlargement of the normal congenitally solitary kidney. Br. J. Urol. 79, 836-841. doi: 10.1046/j.1464-410x.1997.00215.x

Manning, J., and Vehaskari, V. M. (2005). Postnatal modulation of prenatally programmed hypertension by dietary Na and ACE inhibition. Am. J. Physiol. Regul. Integr. Comp. Physiol. 288, R80-R84.

Mansuri, A., Legan, S. K., Jain, J., Alhamoud, I., Gattineni, J., and Baum, M. (2017). Effect of renal denervation on urine angiotensinogen excretion in prenatally programmed rats. Physiol. Rep. 5:e13482. doi: 10.14814/phy2.13482

Marzuillo, P., Guarino, S., Grandone, A., Di Somma, A., Della Vecchia, N., Esposito, T., et al. (2017). Outcomes of a cohort of prenatally diagnosed and early enrolled patients with congenital solitary functioning kidney. J. Urol. 198, 1153-1158. doi: 10.1016/j.juro.2017.05.076 
Marzuillo, P., Guarino, S., Grandone, A., Di Somma, A., Diplomatico, M., Rambaldi, P. F., et al. (2019). Congenital solitary kidney size at birth could predict reduced eGFR levels later in life. J. Perinatol. 39, 129-134. doi: 10.1038/ s41372-018-0260-2

Mauriello, A., Rovella, V., Anemona, L., Servadei, F., Giannini, E., Bove, P., et al. (2015). Increased sympathetic renal innervation in hemodialysis patients is the anatomical substrate of sympathetic hyperactivity in end-stage renal disease. J. Am. Heart Assoc. Cardiovasc. Cerebrovasc. Dis. 4:e002426.

Mavinkurve-Groothuis, A. M., Van De Kracht, F., Westland, R., Van Wijk, J. A., Loonen, J. J., and Schreuder, M. F. (2016). Long-term follow-up of blood pressure and glomerular filtration rate in patients with a solitary functioning kidney: a comparison between Wilms tumor survivors and nephrectomy for other reasons. Pediatr. Nephrol. 31, 435-441. doi: 10.1007/s00467-0153215-2

Monu, S. R., Ren, Y., Masjoan-Juncos, J. X., Kutskill, K., Wang, H., Kumar, N., et al. (2018). Connecting tubule glomerular feedback mediates tubuloglomerular feedback resetting after unilateral nephrectomy. Am. J. Physiol. Renal Physiol. 315, F806-F811.

Monument, M. J., and Smith, F. G. (2003). Age-dependent effects of captopril on the arterial baroreflex control of heart rate in conscious lambs. Exp. Physiol. 88, 761-768. doi: 10.1113/eph8802602

Moritz, K. M., Jefferies, A., Wong, J., Marelyn Wintour, E., and Dodic, M. (2005). Reduced renal reserve and increased cardiac output in adult female sheep uninephrectomized as fetuses. Kidney Int. 67, 822-828. doi: 10.1111/j.15231755.2005.00147.x

Moritz, K. M., Wintour, E. M., Black, M. J., Bertram, J. F., and Caruana, G. (2008), Factors influencing mammalian kidney development: implications for health in adult life. Adv. Anat. Embryol. Cell. Biol. 196, 1-78.

Moritz, K. M., and Wintour, E. M. (1999). Funtional development of the meso- and the metanephros. Pediatr. Nephrol. 13, 171-178. doi: 10.1007/s004670050587

Moritz, K. M., Wintour, E. M., and Dodic, M. (2002). Fetal uninephrectomy leads to postnatal hypertension and compromised renal function. Hypertension 39, 1071-1076. doi: 10.1161/01.hyp.0000019131.77075.54

Mount, P. F., and Power, D. A. (2006). Nitric oxide in the kidney: functions and regulation of synthesis. Acta Physiol. 187, 433-446. doi: 10.1111/j.1748-1716. 2006.01582.x

Müller-Suur, R., Norlén, B.-J., Erik, A., Persson, G., Müller-Suur, C., and Forsmark, B. (1980). Resetting of tubuloglomerular feedback in rat kidneys after unilateral nephrectomy. Kidney Int. 18, 48-57. doi: 10.1038/ki.1980.109

Mulroney, S. E., Woda, C., Johnson, M., and Pesce, C. (1999). Gender differences in renal growth and function after uninephrectomy in adult rats. Kidney Int. 56, 944-953. doi: 10.1046/j.1523-1755.1999.00647.x

Muzaale, A. D., Massie, A. B., Wang, M. C., Montgomery, R. A., Mcbride, M. A., Wainright, J. L., et al. (2014). Risk of end-stage renal disease following live kidney donation. JAMA 311, 579-586.

Nagasu, H., Satoh, M., Kidokoro, K., Nishi, Y., Channon, K. M., Sasaki, T., et al. (2012). Endothelial dysfunction promotes the transition from compensatory renal hypertrophy to kidney injury after unilateral nephrectomy in mice. Am. J. Physiol. Renal Physiol. 302, F1402-F1408.

Nagata, M., Schärer, K., and Kriz, W. (1992). Glomerular damage after uninephrectomy in young rats. I. Hypertrophy and distortion of capillary architecture. Kidney Int. 42, 136-147. doi: 10.1038/ki.1992.271

Niemi, M., and Mandelbrot, D. A. (2014). The outcomes of living kidney donation from medically complex donors: implications for the donor and the recipient. Curr. Transpl. Rep. 1, 1-9. doi: 10.1007/s40472-013-0001-6

Nyengaard, J. R. (1993). Number and dimensions of rat glomerular capillaries in normal development and after nephrectomy. Kidney Int. 43, 1049-1057. doi: 10.1038/ki.1993.147

Palloshi, A., Fragasso, G., Piatti, P., Monti, L. D., Setola, E., Valsecchi, G., et al. (2004). Effect of oral l-arginine on blood pressure and symptoms and endothelial function in patients with systemic hypertension, positive exercise tests, and normal coronary arteries. Am. J. Cardiol. 93, 933-935. doi: 10.1016/j. amjcard.2003.12.040

Poggiali, I. V., Simões, E., Silva, A. C., Vasconcelos, M. A., Dias, C. S., Gomes, I. R., et al. (2019). A clinical predictive model of renal injury in children with congenital solitary functioning kidney. Pediatr. Nephrol. 34, 465-474. doi: 10.1007/s00467-018-4111-3
Pollock, C. A., Bostrom, T. E., Dyne, M., Gyory, A. Z., and Field, M. J. (1992). Tubular sodium handling and tubuloglomerular feedback in compensatory renal hypertrophy. Pflug. Arch. 420, 159-166. doi: 10.1007/bf00374985

Prevot, A., Mosig, D., and Guignard, J. P. (2002). The effects of losartan on renal function in the newborn rabbit. Pediatr. Res. 51, 728-732. doi: 10.1203/01.pdr. 0000015103.96800 .88

Ravani, P., Tripepi, G., Malberti, F., Testa, S., Mallamaci, F., and Zoccali, C. (2005). Asymmetrical dimethylarginine predicts progression to dialysis and death in patients with chronic kidney disease: a competing risks modeling approach. J. Am. Soc. Nephrol. 16, 2449-2455. doi: 10.1681/asn.2005010076

Reyes, A. A., Karl, I. E., Kissane, J., and Klahr, S. (1993). L-arginine administration prevents glomerular hyperfiltration and decreases proteinuria in diabetic rats. J. Am. Soc. Nephrol. 4, 1039-1045.

Robillard, J. E., Weismann, D. N., Gomez, R. A., Ayres, N. A., Lawton, W. J., and Vanorden, D. E. (1983). Renal and adrenal responses to converting-enzyme inhibition in fetal and newborn life. Am. J. Physiol. 244, R249-R256.

Rojas-Canales, D. M., Li, J. Y., Makuei, L., and Gleadle, J. M. (2019). Compensatory renal hypertrophy following nephrectomy: when and how? Nephrology 24, 1225-1232. doi: 10.1111/nep.13578

Romero, C. A., Orias, M., and Weir, M. R. (2015). Novel RAAS agonists and antagonists: clinical applications and controversies. Nat. Rev. Endocrinol. 11, 242-252. doi: 10.1038/nrendo.2015.6

Salmond, R., and Seney, F. D. Jr. (1991). Reset tubuloglomerular feedback permits and sustains glomerular hyperfunction after extensive renal ablation. Am. J. Physiol. 260, F395-F401.

Sanna-Cherchi, S., Ravani, P., Corbani, V., Parodi, S., Haupt, R., Piaggio, G., et al. (2009). Renal outcome in patients with congenital anomalies of the kidney and urinary tract. Kidney Int. 76, 528-533.

Schmidt, R. J., and Baylis, C. (2000). Total nitric oxide production is low in patients with chronic renal disease. Kidney Int. 58, 1261-1266. doi: 10.1046/j.1523-1755. 2000.00281.x

Schreuder, M. F. (2017). Life with one kidney. Pediatr. Nephrol. 33, 595-604. doi: 10.1007/s00467-017-3686-4

Schreuder, M. F., Langemeijer, M. E., Bokenkamp, A., Delemarre-Van De Waal, H. A., and Van Wijk, J. A. (2008). Hypertension and microalbuminuria in children with congenital solitary kidneys. J. Paediatr. Child Health 44, 363-368. doi: 10.1111/j.1440-1754.2008.01315.x

Schreuder, M. F., Westland, R., and Van Wijk, J. A. (2009). Unilateral multicystic dysplastic kidney: a meta-analysis of observational studies on the incidence, associated urinary tract malformations and the contralateral kidney. Nephrol. Dial. Transplant. 24, 1810-1818. doi: 10.1093/ndt/gfn777

Sherman, R. C., and Langley-Evans, S. C. (1998). Early administration of angiotensin-converting enzyme inhibitor captopril, prevents the development of hypertension programmed by intrauterine exposure to a maternal low-protein diet in the rat. Clin. Sci. 94, 373-381. doi: 10.1042/cs094 0373

Sherman, R. C., and Langley-Evans, S. C. (2000). Antihypertensive treatment in early postnatal life modulates prenatal dietary influences upon blood pressure in the rat. Clin. Sci. 98, 269-275. doi: 10.1042/cs0980269

Shirley, D. G., and Walter, S. J. (1991). Acute and chronic changes in renal function following unilateral nephrectomy. Kidney Int. 40, 62-68. doi: 10.1038/ki.1991. 180

Sigmon, D. H., Gonzalez-Feldman, E., Cavasin, M. A., Potter, D. L., and Beierwaltes, W. H. (2004). Role of nitric oxide in the renal hemodynamic response to unilateral nephrectomy. J. Am. Soc. Nephrol. 15, 1413-1420. doi: 10.1097/01.asn.0000130563.67384.81

Singh, R. R., Cuffe, J. S., and Moritz, K. M. (2012). Short- and long-term effects of exposure to natural and synthetic glucocorticoids during development. Clin. Exp. Pharmacol. Physiol. 39, 979-989. doi: 10.1111/1440-1681.12009

Singh, R. R., Denton, K. M., Bertram, J. F., Jefferies, A. J., Head, G. A., Lombardo, P., et al. (2009). Development of cardiovascular disease due to renal insufficiency in male sheep following fetal unilateral nephrectomy. J. Hypertens. 27, 386-396. doi: 10.1097/hjh.0b013e32831bc778

Singh, R. R., Denton, K. M., Bertram, J. F., Jefferies, A. J., and Moritz, K. M. (2010). Reduced nephron endowment due to fetal uninephrectomy impairs renal sodium handling in male sheep. Clin. Sci. 118, 669-680. doi: 10.1042/ cs20090479 
Singh, R. R., Easton, L. K., Booth, L. C., Schlaich, M. P., Head, G. A., Moritz, K. M., et al. (2016). Renal nitric oxide deficiency and chronic kidney disease in young sheep born with a solitary functioning kidney. Sci. Rep. 6:26777.

Singh, R. R., Mcardle, Z. M., Iudica, M., Easton, L. K., Booth, L. C., May, C. N., et al. (2019). Sustained decrease in blood pressure and reduced anatomical and functional reinnervation of renal nerves in hypertensive sheep 30 months after catheter-based renal denervation. Hypertension 73, 718-727. doi: 10.1161/ hypertensionaha.118.12250

Singh, R. R., Moritz, K. M., Wintour, E. M., Jefferies, A. J., Iqbal, J., Bertram, J. F., et al. (2011). Fetal uninephrectomy in male sheep alters the systemic and renal responses to angiotensin II infusion and AT1R blockade. Am. J. Physiol. Renal Physiol. 301, F319-F326.

Singh, R. R., Sajeesh, V., Booth, L. C., Mcardle, Z., May, C. N., Head, G. A., et al. (2017). Catheter-based renal denervation exacerbates blood pressure fall during hemorrhage. J. Am. Coll. Cardiol. 69, 951-964. doi: 10.1016/j.jacc.2016.12.014

Skov, K., Nyengaard, J. R., Korsgaard, N., and Mulvany, M. J. (1994). Number and size of renal glomeruli in spontaneously hypertensive rats. J. Hypertens. 12, 1373-1376.

Snoek, R., De Heus, R., De Mooij, K. J., Pistorius, L. R., Lilien, M. R., Lely, A. T., et al. (2018). Assessing nephron hyperplasia in fetal congenital solitary functioning kidneys by measuring renal papilla number. Am. J. Kidney Dis. 72, 465-467. doi: 10.1053/j.ajkd.2018.03.018

Srivastava, T., Alon, U. S., Cudmore, P. A., Tarakji, B., Kats, A., Garola, R. E., et al. (2014a). Cyclooxygenase-2, prostaglandin E2, and prostanoid receptor EP2 in fluid flow shear stress-mediated injury in the solitary kidney. Am. J. Physiol. Renal Physiol. 307, F1323-F1333.

Srivastava, T., Celsi, G. E., Sharma, M., Dai, H., Mccarthy, E. T., Ruiz, M., et al. (2014b). Fluid flow shear stress over podocytes is increased in the solitary kidney. Nephrol. Dial. Transplant. 29, 65-72. doi: 10.1093/ndt/gft387

Srivastava, T., Ju, W., Milne, G. L., Rezaiekhaligh, M. H., Staggs, V. S., Alon, U. S., et al. (2020). Urinary prostaglandin E2 is a biomarker of early adaptive hyperfiltration in solitary functioning kidney. Prostaglandins Other Lipid Mediat. 146:106403. doi: 10.1016/j.prostaglandins.2019.106403

Srivastava, T., Mccarthy, E. T., Sharma, R., Cudmore, P. A., Sharma, M., Johnson, M. L., et al. (2010). Prostaglandin E(2) is crucial in the response of podocytes to fluid flow shear stress. J. Cell Commun. Signal. 4, 79-90. doi: 10.1007/s12079010-0088-9

Srivastava, T., Thiagarajan, G., Alon, U. S., Sharma, R., El-Meanawy, A., Mccarthy, E. T., et al. (2017). Role of biomechanical forces in hyperfiltration-mediated glomerular injury in congenital anomalies of the kidney and urinary tract. Nephrol. Dial. Transplant. 32, 759-765. doi: 10.1093/ndt/gfw430

Stefanowicz, J., Owczuk, R., Kaluzynska, B., Aleksandrowicz, E., Owczarzak, A., Adamkiewicz-Drozynska, E., et al. (2012). Renal function and solitary kidney disease: wilms tumour survivors versus patients with unilateral renal agenesis. Kidney Blood Press. Res. 35, 174-181. doi: 10.1159/000332083

Symplicity, H. T. N. I. (2011). Catheter-based renal sympathetic denervation for resistant hypertension: durability of blood pressure reduction out to 24 months. Hypertension 57, 911-917. doi: 10.1161/hypertensionaha.110.163014

Tain, Y.-L., Freshour, G., Dikalova, A., Griendling, K., and Baylis, C. (2007). Vitamin E reduces glomerulosclerosis, restores renal neuronal NOS, and suppresses oxidative stress in the 5/6 nephrectomized rat. Am. J. Physiol. Renal Physiol. 292, F1404-F1410.

Tain, Y. L., Luh, H., Lin, C. Y., and Hsu, C. N. (2016). Incidence and risks of congenital anomalies of kidney and urinary tract in newborns: a populationbased case-control study in Taiwan. Medicine 95:e2659. doi: 10.1097/md. 0000000000002659

Taranta-Janusz, K., Wasilewska, A., Stypulkowska, J., and Sutula, M. (2012). Osteopontin and symmetric dimethylarginine plasma levels in solitary functioning kidney in children. Acta Paediatr. 101, e369-e372. doi: 10.1111/ j.1651-2227.2012.02690.x

Taranta-Janusz, K., Zalewska-Szajda, B., Gościk, E., Chojnowska, S., Dmochowska, M., Pszczółkowska, M., et al. (2014). New tubular injury markers in children with a solitary functioning kidney. Pediatr. Nephrol. 29, 1599-1605. doi: 10. 1007/s00467-014-2802-y

Van Den Belt, S. M., Heerspink, H. J. L., Gracchi, V., De Zeeuw, D., Wuhl, E., Schaefer, F., et al. (2018). Early proteinuria lowering by angiotensin-converting enzyme inhibition predicts renal survival in children with CKD. J. Am. Soc. Nephrol. 29, 2225-2233. doi: 10.1681/asn.2018010036
Van Vuuren, S. H., Sol, C. M., Broekhuizen, R., Lilien, M. R., Oosterveld, M. J. S., Nguyen, T. Q., et al. (2012a). Compensatory growth of congenital solitary kidneys in pigs reflects increased nephron numbers rather than hypertrophy. PLoS One 7:e49735. doi: 10.1371/journal.pone.0049735

Van Vuuren, S. H., Van Der Doef, R., Cohen-Overbeek, T. E., Goldschmeding, R., Pistorius, L. R., and De Jong, T. P. (2012b). Compensatory enlargement of a solitary functioning kidney during fetal development. Ultrasound Obstet. Gynecol. 40, 665-668. doi: 10.1002/uog.11168

Velaphi, S. C., Despain, K., Roy, T., and Rosenfeld, C. R. (2007). The reninangiotensin system in conscious newborn sheep: metabolic clearance rate and activity. Pediatr. Res. 61, 681-686. doi: 10.1203/pdr.0b013e3180534252

Vinturache, A. E., and Smith, F. G. (2016). Renal effects of angiotensin II in the newborn period: role of type 1 and type 2 receptors. BMC Physiol. 16:3. doi: 10.1186/s12899-016-0022-3

Walton, S. L., Bielefeldt-Ohmann, H., Singh, R. R., Li, J., Paravicini, T. M., Little, M. H., et al. (2017). Prenatal hypoxia leads to hypertension, renal reninangiotensin system activation and exacerbates salt-induced pathology in a sex-specific manner. Sci. Rep. 7:8241.

Wang, M., Han, W., Zhang, M., Fang, W., Zhai, X., Guan, S., et al. (2018). Longterm renal sympathetic denervation ameliorates renal fibrosis and delays the onset of hypertension in spontaneously hypertensive rats. Am. J. Transl. Res. 10, 4042-4053.

Wang, M. K., Gaither, T., Phelps, A., Cohen, R., and Baskin, L. (2019). The incidence and durability of compensatory hypertrophy in pediatric patients with solitary kidneys. Urology 129, 188-193. doi: 10.1016/j.urology.2019.04.003

Wang, Y., Wang, Z., Wang, W., Ren, H., Zhang, W., and Chen, N. (2010). Analysis of factors associated with renal function in chinese adults with congenital solitary kidney. Intern. Med. 49, 2203-2209. doi: 10.2169/internalmedicine.49. 3742

Wasilewska, A., Zoch-Zwierz, W., Jadeszko, I., Porowski, T., Biernacka, A., Niewiarowska, A., et al. (2006). Assessment of serum cystatin C in children with congenital solitary kidney. Pediatr. Nephrol. 21, 688-693. doi: 10.1007/s00467006-0065-y

Westland, R., Kurvers, R. A., Van Wijk, J. A., and Schreuder, M. F. (2013a). Risk factors for renal injury in children with a solitary functioning kidney. Pediatrics 131, e478-e485. doi: 10.1542/peds.2012-2088

Westland, R., and Schreuder, M. F. (2014). Gender differences in solitary functioning kidney: do they affect renal outcome? Pediatr. Nephrol. 29, 22432244. doi: 10.1007/s00467-013-2473-0

Westland, R., Schreuder, M. F., Bokenkamp, A., Spreeuwenberg, M. D., and Van Wijk, J. A. (2011). Renal injury in children with a solitary functioning kidneythe KIMONO study. Nephrol. Dial. Transplant. 26, 1533-1541. doi: 10.1093/ ndt/gfq844

Westland, R., Schreuder, M. F., Ket, J. C., and Van Wijk, J. A. (2013b). Unilateral renal agenesis: a systematic review on associated anomalies and renal injury. Nephrol. Dial. Transplant. 28, 1844-1855. doi: 10.1093/ndt/gft012

Westland, R., Schreuder, M. F., Van Der Lof, D. F., Vermeulen, A., Dekker-Van Der Meer, I. M., Bokenkamp, A., et al. (2014). Ambulatory blood pressure monitoring is recommended in the clinical management of children with a solitary functioning kidney. Pediatr. Nephrol. 29, 2205-2211. doi: 10.1007/ s00467-014-2853-0

Woods, L. L. (1999). Neonatal uninephrectomy causes hypertension in adult rats. Am. J. Physiol. 276, R974-R978.

Woods, L. L., Ingelfinger, J. R., Nyengaard, J. R., and Rasch, R. (2001a). Maternal protein restriction suppresses the newborn renin-angiotensin system and programs adult hypertension in rats. Pediatr. Res. 49, 460-467. doi: 10.1203/ 00006450-200104000-00005

Woods, L. L., Weeks, D. A., and Rasch, R. (2001b). Hypertension after neonatal uninephrectomy in rats precedes glomerular damage. Hypertension 38, 337342. doi: 10.1161/01.hyp.38.3.337

Wuhl, E., Trivelli, A., Picca, S., Litwin, M., Peco-Antic, A., Zurowska, A., et al. (2009). Strict blood-pressure control and progression of renal failure in children. N. Engl. J. Med. 361, 1639-1650. doi: 10.1056/nejmoa 0902066

Wuhl, E., Van Stralen, K. J., Verrina, E., Bjerre, A., Wanner, C., Heaf, J. G., et al. (2013). Timing and outcome of renal replacement therapy in patients with congenital malformations of the kidney and urinary tract. Clin. J. Am. Soc. Nephrol. 8, 67-74. doi: 10.2215/cjn.03310412 
Xu, Q., Wu, H., Zhou, L., Xie, J., Zhang, W., Yu, H., et al. (2019). The clinical characteristics of Chinese patients with unilateral renal agenesis. Clin. Exp. Nephrol. 23, 792-798. doi: 10.1007/s10157-019-01704-x

Zambaiti, E., Sergio, M., Baldanza, F., Corrado, C., Di Pace, M. R., and Cimador, M. (2019). Correlation between hypertrophy and risk of hypertension in congenital solitary functioning kidney. Pediatr. Surg. Int. 35, 167-174. doi: 10.1007/ s00383-018-4389-z

Zoccali, C., Bode-Boger, S., Mallamaci, F., Benedetto, F., Tripepi, G., Malatino, L., et al. (2001). Plasma concentration of asymmetrical dimethylarginine and mortality in patients with end-stage renal disease: a prospective study. Lancet 358, 2113-2117. doi: 10.1016/s0140-6736(01)07217-8
Conflict of Interest: The authors declare that the research was conducted in the absence of any commercial or financial relationships that could be construed as a potential conflict of interest.

Copyright (๑) 2020 McArdle, Schreuder, Moritz, Denton and Singh. This is an openaccess article distributed under the terms of the Creative Commons Attribution License (CC BY). The use, distribution or reproduction in other forums is permitted, provided the original author(s) and the copyright owner(s) are credited and that the original publication in this journal is cited, in accordance with accepted academic practice. No use, distribution or reproduction is permitted which does not comply with these terms. 